\title{
54. GEOCHEMISTRY OF THE JAPAN TRENCH SEDIMENTS RECOVERED ON DEEP SEA DRILLING PROJECT LEGS 56 AND 57
}

\author{
Ivar Murdmaa, Vyacheslav Gordeev, Tatyana Kuzmina, Natalia Turanskaya, \\ P. P. Shirshov Institute of Oceanology, U.S.S.R. Academy of Sciences, Moscow, U.S.S.R. \\ and \\ Mark Mikhailov, Far-East Geological Institute, U.S.S.R. Academy of Sciences, Vladivostok, U.S.S.R.
}

\section{INTRODUCTION}

The main objective of this investigation was to study distribution of main chemical constituents and several minor elements in sediment sections drilled during DSDP Legs 56 and 57 in the Japan Trench, in order to infer geochemical features of different lithologic types of sediments, and to find out how the geochemistry is associated with major lithologic constituents, such as terrigenous detrital matter, clay, volcanic ash, and biogenic particles. The geochemical data may help to indicate the nature of the sediments and to interpret sedimentation processes.

The analyzed samples seem to be representative of most lithologic units, sub-units, and sediment types drilled at all sites on both legs, except for some shallowwater deposits at Sites 438 and 439 . We analyzed bulksediment composition by X-ray fluorescence (Kuzmina and Turanskaya) and routine wet-chemical methods (Mikhailov); amorphous $\mathrm{SiO}_{2}$, extracted in a boiling sodium carbonate solution (Analythical Laboratory, P. $\mathrm{P}$. Shirshov Institute of Oceanology); $\mathrm{Cr}, \mathrm{Zn}, \mathrm{Cu}, \mathrm{Ni}$, $\mathrm{Co}$, and $\mathrm{Al}$ by atomic absorption (Gordeev); and $\mathrm{Sn}$, $\mathrm{Pb}, \mathrm{Zn}, \mathrm{Cu}, \mathrm{Ni}, \mathrm{Co}, \mathrm{Cr}, \mathrm{V}, \mathrm{B}$, and $\mathrm{Ag}$ by quantitative spectrographic analyses in both bulk samples and granulometric fractions (Mikhailov). In addition, $\mathrm{Fe}$, $\mathrm{Ti}, \mathrm{Mn}$, and $\mathrm{CaCO}_{3}$ have been determined in selected samples by routine wet-chemical methods (Analytical Laboratory, P. P. Shirshov Institute of Oceanology). Murdmaa was responsible for interpretation of the results.

\section{SILICA}

We determined both total silica content in sediments, using X-ray fluorescence, and so-called "amorphous", silica, i.e., that extractable by boiling sodium carbonate solution. The "amorphous" $\mathrm{SiO}_{2}$ is supposed to be incorporated in biogenic opal (diatoms, radiolarians, sponge spicules), but the percentages obtained are commonly underestimated because of incomplete dissolution of the opal skeletons.

In addition, we calculated "excess" silica with respect to the "normal" terrigenous clay matrix, using Boström's (1976) equation (somewhat modified):

$$
\text { "excess" } \mathrm{SiO}_{2}=\text { total } \mathrm{SiO}_{2}-\left(3.5 \times \mathrm{Al}_{2} \mathrm{O}_{3}\right) \text {, }
$$

where the total $\mathrm{SiO}_{2}$ and $\mathrm{Al}_{2} \mathrm{O}_{3}$ are derived from X-ray fluorescence bulk analyses. The calculation is based on the assumption that the $\mathrm{SiO}_{2} / \mathrm{Al}_{2} \mathrm{O}_{3}$ ratio in terrigenous clay and silty clay is almost constant, averaging about 3.5 (approximately the same as the $\mathrm{Si} / \mathrm{Al}$ ratio 6.6 used by Boström). The larger values of the ratio mean therefore that some "excess" silica is present, as compared with the "normal" clay matrix and defined as $3.5 \times$ $\mathrm{Al}_{2} \mathrm{O}_{3}$. The "excess" silica may be related to terrigenous clastic minerals, quartz first of all, or to acidic vitric ash, which contains up to 72 percent of total $\mathrm{SiO}_{2}$ $\left(\mathrm{SiO}_{2} / \mathrm{Al}_{2} \mathrm{O}_{3}\right.$ ratio up to 6), in the western North Pacific ash layers (Repechka, 1974). But most of it in common deep-sea sediments represents biogenic opaline silica (Boström, 1976), and so the "excess" silica may be used to evaluate the relative amounts of opaline silica, if the quartz and acidic-ash contents are not too high.

The Japan Trench sediments contain more or less abundant vitric ash, mostly of acidic (rhyolitic-dacitic) composition, as indicated by the low refraction index of the glass shards. The volcanoclastic constituent is likely responsible for a certain part of the "excess" silica in these sediments, along with biogenic opal. We are not able to estimate the proportion of this "volcanoclastic" silica; however, an apparent correlation between the "amorphous" and "excess" silica values (Figure 1) indicates that major variations in both total $\mathrm{SiO}_{2}$ and excess silica are likely related to those of biogenic opal.

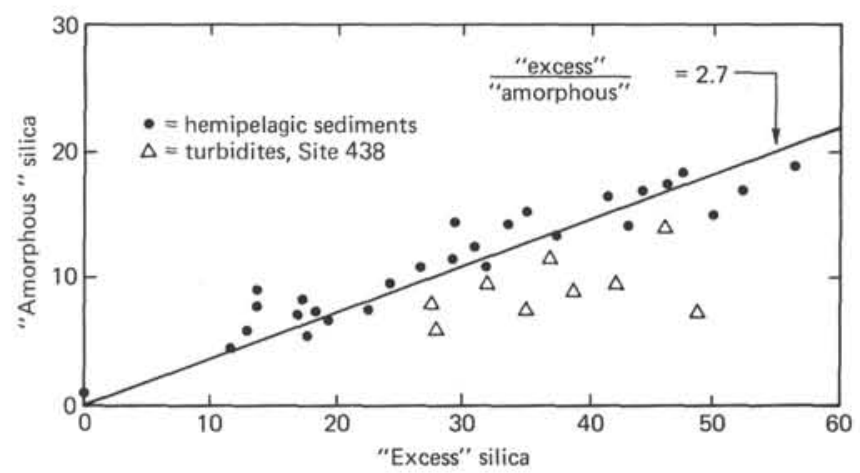

Figure 1. Plot of biogenic silica content, as estimated by double extraction in boiling sodium carbonate solution ("amorphous" silica), against "excess" sili$\mathrm{ca}$, calculated from bulk analyses of the same samples, using the equation "excess" $\mathrm{SiO}_{2}=$ total $\mathrm{SiO}_{2}$ - $\left(3.5 \times \mathrm{Al}_{2} \mathrm{O}_{3}\right)$. The ratio of 2.7 approximates the relation for hemipelagic sediments. 
The Neogene to Quaternary hemipelagic sediments at all sites are markedly enriched in total silica with respect to "normal" hemipelagic clay (Tables 1 and 2). Total $\mathrm{SiO}_{2}$ generally ranges from 54 to 76 per cent, and most samples contain more than 60 percent $\mathrm{SiO}_{2}$. The $\mathrm{SiO}_{2} / \mathrm{Al}_{2} \mathrm{O}_{3}$ ratio generally ranges from 4.2 to 15.2 , and values more than 5 predominate over lower ones. The siliceous sediments proper, which contain above 70 percent $\mathrm{SiO}_{2}$, however, are rather rare. These occur occasionally at Sites 434 and 440 , but predominate in subunit Ib at Site 435, as well as in sub-unit IIa at Site 438. Both silica-rich Pliocene intervals have been classified as muddy diatomaceous ooze according to shipboard smear-slide description.

The vertical distribution of total $\mathrm{SiO}_{2}$ in hemipelagic sections at different sites (Figures 2-6), although somewhat chaotic, shows certain general trends. There is a downhole increase in the silica concentration in the transition from Quaternary to Pliocene, and a faint decrease in the transition from Pliocene to upper Miocene, at all sites. The silica content is highest in the Pliocene sections of the upper trench slope (averages of $70.3 \%$ at Sites 435 and 438 ); it decreases towards lower slope (Sites 440, 69.7\%; Site 434, 65.4\%), and is minimal in the corresponding section on the oceanic slope (Site 436), where it averages at 62.1 per cent. Quaternary sediments are most enriched in total silica at Site 440 $(59-65 \%$, average $61.7 \%)$ and at Site $435(57-70 \%$, average $61.7 \%$ ), whereas silica content in the oceanic slope Quaternary section at Site 436 is somewhat lower $(55-66 \%$, average $59.0 \%$ ). In the Miocene, the silica content is highest at Sites 438 (average 68.8\%) and 440 (average of two samples $70.8 \%$ ), and decreases seaward (average of two samples at Site $43462.6 \%$; a single determination at Site 441 shows $63.4 \%$ ). Again, we found the lowest values on the oceanic slope at Site 436 where there is an average at $\mathbf{5 7 . 4 \%}$ (the transitional unit II is included).

All hemipelagic diatomaceous sediments appear to contain "excess" silica in appreciable amounts (10$57 \%$ ). The variation curves (Figures 2-6) tend to parallel those for total silica, although there are some regular deviations at Sites 438 and 435 caused by changes in $\mathrm{Al}_{2} \mathrm{O}_{3}$. Apparently, an essential portion of the aluminum on the upper trench slope is associated with plagioclase and lithic ash, which decrease the $\mathrm{SiO}_{2} / \mathrm{Al}_{2} \mathrm{O}_{3}$ ratio with respect to the "normal" clay matrix.

"Excess" silica, as well as total silica, is highest (above $40 \%$ ) in the lower-Pliocene sediments at Sites 438 and 435 , on the upper trench slope, where diatoms are most abundant according to smear-slide descriptions. However, values up to 50 per cent "excess"' silica were detected also in some lower-Pliocene sediments at Site 434 , and values of 42 to 46 per cent characterize a long interval (434 to $757 \mathrm{~m}$ in our samples) of Pliocene to upper-Miocene sediments at Site 440 , belonging to unit III. The shipboard sedimentologists of Leg 57 described the latter as lithified "claystone and diatoma- ceous claystone," which contain rather small amounts of biogenic opaline particles (see Site 440 report, this volume). We suppose that biogenic particles may have been partly dissolved and the silica redeposited as authigenic opal during diagenesis, although authigenic minerals of silica (opal-CT) were not found by X-ray diffractometry (Müller, this volume).

In any case, at all sites the "excess" silica, represented mainly by biogenic opal, tends to increase from the upper Pleistocene to the lower Pleistocene and Pliocene; it reaches its maximum in certain layers of lower Pliocene and decreases then through the upper to middle Miocene (Figures 2-6). On the other hand, in each correlated stratigraphic interval the "excess" silica decreases from the upper landward trench slope to the oceanic slope.

The sodium-extracted "amorphous" silica content in the hemipelagic sediments ranges from 4.7 to 18.4 per cent (Table 3), roughly correlating with the "excess" silica (Figure 1). The factor 2.7, which approximates the relation, is much greater, however, than that usually detected in Holocene diatomaceous sediments. Hence, the biogenic silica in the Japan Trench sediments is likely less soluble under the treatment we used.

Distribution patterns of the "amorphous" silica are similar to those of the total and "excess" silica. The highest values we found were at Site 435 , where the average "amorphous"-silica content is 7.5 per cent in Quaternary sediments, 17.1 per cent in upper-Pliocene sediments, and 17.4 per cent in lower-Pliocene sediments. At Site 440 , the averages for corresponding age intervals are $9.2,13.2$ and 12 per cent, respectively.

At Site 438, the average content of "amorphous" silica is 15.1 per cent in the upper Pliocene, 13.9 per cent in the lower Pliocene, and 8.4 per cent in the upper Miocene, the values being somewhat lower than those for Site 435. The average of two samples from the upper Pliocene at Site 434 is 12.6 per cent, whereas lowerPliocene sediments at this site contain 12.6 per cent "amorphous" silica. The average concentrations of "amorphous" silica throughout the oceanic slope hemipelagic section are constantly lower: 7.1 per cent in the Quaternary, 6.5 per cent in the upper Pliocene, 6.9 per cent in the lower Pliocene, and 7.4 per cent in the upper Miocene.

The transitions from the hemipelagic section to the lower-Miocene turbidites at Sites 438 and 439 (unit IV), and then to the upper-Oligocene sandstones and siltstones (Unit $\mathrm{V}$ ) do not show any certain influence on the total $\mathrm{SiO}_{2}$ content (Figure 2). However, the calculated "excess" silica decreases markedly, in good accordance with decreasing biogenic silica and increasing $\mathrm{Al}_{2} \mathrm{O}_{3}$ of feldspars and lithic particles. The high total $\mathrm{SiO}_{2}$ content (63-68\%) points to an "acidic" composition of the source clastic material in these sediments, which is confirmed by lithologic description of thin sections. The analyzed samples of the Upper Cretaceous clayey siltstone (shale) from Site 439 (Cores 439-38 and 439-39) contain 63 and 61 per cent total silica, respectively, but 
TABLE 1

Bulk Analyses (X-ray fluorescence) of the Legs 56 and 57 Sediments

\begin{tabular}{|c|c|c|c|c|c|c|c|c|c|c|c|c|}
\hline $\begin{array}{l}\text { Sample } \\
\text { (interval in } \mathrm{cm} \text { ) }\end{array}$ & $\mathrm{SiO}_{2}$ & $\mathrm{TiO}_{2}$ & $\mathrm{Al}_{2} \mathrm{O}_{3}$ & $\mathrm{Fe}_{2} \mathrm{O}_{3} \mathrm{a}$ & $\mathrm{MnO}$ & $\mathrm{MgO}$ & $\mathrm{CaO}$ & $\mathrm{K}_{2} \mathrm{O}$ & $\mathrm{Na}_{2} \mathrm{O}$ & L.o.i. & $\frac{\mathrm{SiO}_{2}}{\mathrm{Al}_{2} \mathrm{O}_{3}}$ & $\begin{array}{l}\text { "Excess" } \\
\mathrm{SiO}_{2}{ }^{\mathrm{b}}\end{array}$ \\
\hline $434-1-2,64-69$ & 61.2 & 0.45 & 11.70 & 4.70 & 0.08 & 1.69 & 2.02 & 1.52 & 3.21 & 13.00 & 5.23 & 20.2 \\
\hline $2-1,89-93$ & 63.7 & 0.48 & 10.02 & 4.85 & 0.06 & 2.60 & 1.10 & 1.66 & 3.52 & 12.00 & 6.36 & 28.6 \\
\hline $5-1,130-134^{c}$ & 54.4 & 0.35 & 8.88 & 17.15 & 0.23 & 2.18 & 1.82 & 1.33 & 3.80 & 9.73 & 6.46 & 23.3 \\
\hline $11, \mathrm{CC}, 5-9$ & 67.3 & 0.46 & 10.10 & 4.28 & 0.10 & 2.10 & 1.33 & 1.59 & 2.59 & 10.10 & 6.66 & 32.0 \\
\hline $16-1,78-82$ & 67.2 & 0.41 & 9.25 & 3.64 & 0.07 & 1.99 & 1.06 & 1.40 & 3.52 & 11.20 & 7.26 & 34.8 \\
\hline $20-1,54-58$ & 66.5 & 0.41 & 10.11 & 4.09 & 0.06 & 0.98 & 1.17 & 1.83 & 2.99 & 10.70 & 6.57 & 31.1 \\
\hline $28-1,100-102$ & 63.6 & 0.49 & 11.00 & 6.28 & 0.17 & 1.58 & 1.89 & 1.98 & 2.28 & 9.50 & 5.78 & 25.1 \\
\hline $28-2,26-28$ & 72.5 & 0.38 & 8.27 & 3.52 & 0.15 & 1.45 & 0.97 & 1.43 & 2.45 & 8.61 & 8.77 & 43.6 \\
\hline $31-1,47-51$ & 65.6 & 0.47 & 11.00 & 5.55 & 0.10 & 2.30 & 0.97 & 1.69 & 2.57 & 9.68 & 5.96 & 27.1 \\
\hline 434B-9-2, 48-51 & 73.6 & 0.28 & 6.82 & 2.78 & 0.18 & 1.02 & 0.88 & 1.00 & 3.70 & 9.44 & 10.79 & 49.7 \\
\hline $9-2,110-114$ & 75.7 & 0.30 & 7.23 & 2.49 & 0.05 & 0.66 & 0.65 & 1.10 & 2.39 & 9.27 & 10.47 & 50.4 \\
\hline $11-1,100-102$ & 55.3 & 0.32 & 8.67 & 6.36 & 0.33 & 2.14 & 10.50 & 1.59 & 2.07 & 11.20 & 6.38 & 25.0 \\
\hline $13, \mathrm{CC}$ & 30.2 & 0.11 & 6.21 & 1.92 & 0.48 & 3.11 & 25.60 & 8.63 & 0.93 & 25.60 & 4.86 & 8.5 \\
\hline $24-1,24-30$ & 60.7 & 0.50 & 11.75 & 4.83 & 0.12 & 1.47 & 0.62 & 2.11 & 8.70 & 9.01 & 5.17 & 19.6 \\
\hline $34-1,82-86$ & 64.5 & 0.60 & 11.20 & 5.00 & 0.08 & 1.83 & 2.42 & 1.31 & 4.20 & 8.68 & 5.76 & 25.3 \\
\hline $435-4-1,50-54$ & 63.0 & 0.46 & 10.30 & 4.45 & 0.07 & 3.13 & 0.82 & 1.57 & 3.12 & 12.12 & 6.11 & 27.0 \\
\hline $4-1,102-106$ & 57.0 & 0.39 & 11.18 & 3.94 & 0.06 & 1.46 & 7.44 & 1.68 & 3.19 & 12.50 & 5.10 & 17.9 \\
\hline $6-4,90-94$ & 70.0 & 0.39 & 11.52 & 3.92 & 0.13 & 0.91 & 1.28 & 1.35 & 2.88 & 7.56 & 6.08 & 29.7 \\
\hline $9-3,50-52$ & 66.5 & 0.46 & 9.36 & 4.34 & 0.06 & 2.07 & 2.14 & 1.42 & 3.35 & 9.95 & 7.10 & 33.7 \\
\hline $11-1,64-67$ & 69.6 & 0.51 & 9.15 & 3.50 & 0.05 & 2.04 & 1.15 & 1.31 & 3.63 & 9.58 & 7.61 & 37.6 \\
\hline $13-1,90-94$ & 66.4 & 0.42 & 9.98 & 3.79 & 0.05 & 1.70 & 1.91 & 1.65 & 4.22 & 9.82 & 6.65 & 29.5 \\
\hline $15-3,31-35$ & 73.4 & 0.31 & 4.81 & 2.63 & 0.04 & 2.20 & 0.73 & 1.05 & 4.21 & 10.42 & 15.26 & 56.6 \\
\hline $435 \mathrm{~A}-2-1,38-42$ & 73.0 & 0.29 & 5.98 & 2.58 & 0.04 & 2.10 & 1.22 & 0.92 & 3.11 & 10.32 & 12.21 & 52.1 \\
\hline $3-1,38-39$ & 68.2 & 0.39 & 12.90 & 2.88 & 0.08 & 0.74 & 1.65 & 2.58 & 3.76 & 6.17 & 5.29 & 23.0 \\
\hline $4-3,50-54$ & 70.7 & 0.36 & 8.22 & 3.05 & 0.05 & 2.14 & 1.31 & 1.27 & 2.40 & 10.20 & 8.60 & 41.9 \\
\hline $5-5,49-52$ & 71.6 & 0.33 & 7.71 & 3.38 & 0.04 & 1.25 & 0.94 & 0.87 & 3.44 & 10.20 & 9.29 & 44.6 \\
\hline $6-2,58-62$ & 72.5 & 0.36 & 7.12 & 3.10 & 0.04 & 1.83 & 1.03 & 0.70 & 3.28 & 9.74 & 10.18 & 47.6 \\
\hline $9-2,100-104$ & 71.5 & 0.32 & 7.31 & 3.12 & 0.04 & 1.36 & 0.75 & 0.77 & 3.23 & 11.15 & 9.78 & 45.9 \\
\hline $436-3-1,100-104$ & 58.3 & 0.62 & 13.40 & 5.74 & 0.07 & 3.30 & 1.6 & 2.31 & 5.72 & 8.4 & 4.35 & 11.4 \\
\hline $44,88-92$ & 58.2 & 0.61 & 12.90 & 5.55 & 0.07 & 3.21 & 1.45 & 2.36 & 5.70 & 9.56 & 4.51 & 13.0 \\
\hline $7-4,50-54$ & 65.6 & 0.38 & 11.60 & 3.40 & 0.09 & 1.72 & 1.09 & 2.18 & 4.70 & 8.75 & 5.66 & 25.0 \\
\hline $11-3,90-94$ & 63.4 & 0.44 & 13.10 & 4.33 & 0.07 & 2.26 & 1.08 & 2.65 & 4.13 & 8.40 & 4.84 & 17.6 \\
\hline $14-3,54-55$ & 67.0 & 0.32 & 11.70 & 2.99 & 0.06 & 1.45 & 1.27 & 2.50 & 3.58 & 8.34 & 5.72 & 26.0 \\
\hline $15-5,60-64$ & 63.5 & 0.48 & 12.85 & 4.11 & 0.07 & 2.54 & 1.66 & 2.22 & 3.96 & 8.29 & 4.94 & 18.5 \\
\hline $19-1,94-98$ & 64.5 & 0.49 & 12.00 & 4.50 & 0.07 & 2.07 & 1.70 & 1.83 & 4.00 & 8.67 & 5.38 & 22.5 \\
\hline $21-1,50-54$ & 60.6 & 0.52 & 12.51 & 5.45 & 0.06 & 2.77 & 1.07 & 2.19 & 5.58 & 8.84 & 4.84 & 16.8 \\
\hline $22-1,75-78$ & 59.21 & 0.42 & 11.57 & 5.22 & 0.06 & 2.28 & 0.95 & 2.46 & 6.30 & 11.51 & 5.12 & 18.7 \\
\hline $24-1,80-84$ & 61.3 & 0.54 & 12.67 & 4.92 & 0.07 & 2.37 & 1.02 & 2.33 & 5.06 & 9.53 & 4.84 & 17.0 \\
\hline $29-1,50-54$ & 62.6 & 0.44 & 12.00 & 3.74 & 0.07 & 2.30 & 0.86 & 2.30 & 3.42 & 10.70 & 5.22 & 20.6 \\
\hline $34-1,60-64$ & 59.7 & 0.53 & 13.13 & 5.87 & 0.20 & 2.05 & 1.05 & 2.24 & 6.05 & 9.25 & 4.55 & 13.7 \\
\hline $34-1,85-87$ & 58.3 & 0.55 & 12.80 & 5.62 & 0.23 & 1.84 & 0.86 & 2.19 & 8.11 & 9.40 & 4.56 & 13.5 \\
\hline $38-1,96-100$ & 59.8 & 0.54 & 12.90 & 5.58 & 0.52 & 2.16 & 0.83 & 2.41 & 4.91 & 9.75 & 4.64 & 14.6 \\
\hline $39-1,102-105$ & 49.5 & 0.67 & 16.00 & 7.25 & 1.81 & 2.97 & 0.59 & 2.82 & 7.46 & 10.50 & 3.09 & - \\
\hline $40-6,48-52$ & 50.9 & 0.65 & 16.55 & 7.12 & 2.25 & 2.38 & 0.84 & 3.47 & 2.59 & 13.25 & 3.08 & - \\
\hline $42-1,15-20$ & 87.0 & 0.09 & 2.10 & 1.85 & 0.44 & 0.78 & 0.45 & 0.36 & 1.62 & 5.34 & 41.41 & 79.6 \\
\hline $438-3-2,100-104$ & 57.2 & 0.54 & .80 & & 0.0 & 2.5 & 7. & 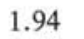 & 2 & 10 & 4.84 & 15.9 \\
\hline $10-2,112-116$ & 67.9 & 0.50 & 10.19 & 4.62 & 0.06 & 1.78 & 2.31 & 1.75 & 2.01 & 7.98 & 6.66 & 32.3 \\
\hline $438 \mathrm{~A}-12-2,33-37$ & 70.8 & 0.34 & 6.95 & 2.91 & 0.04 & 2.18 & 1.27 & 1.17 & 2.82 & 10.35 & 10.20 & 46.0 \\
\hline $18-2,65-69$ & 70.7 & 0.38 & 8.00 & 3.20 & 0.04 & 0.37 & 0.91 & 1.28 & 2.90 & 9.82 & 8.82 & 42.7 \\
\hline $26-2,39-43$ & 72.1 & 0.35 & 7.07 & 3.31 & 0.04 & 1.54 & 1.01 & 1.12 & 2.86 & 9.52 & 10.20 & 47.4 \\
\hline $36-2,50-54$ & 73.7 & 0.34 & 7.08 & 2.90 & 0.04 & 1.42 & 0.74 & 1.06 & 1.86 & 8.95 & 10.40 & 48.9 \\
\hline $42-2,90-94$ & 70.0 & 0.46 & 9.24 & 4.91 & 0.06 & 1.01 & 1.23 & 1.59 & 3.50 & 8.02 & 7.57 & 37.6 \\
\hline $46-2,8-12$ & 71.3 & 0.44 & 8.21 & 3.94 & 0.05 & 1.80 & 0.77 & 1.37 & 2.38 & 8.76 & 8.69 & 42.6 \\
\hline $49-2,60-62$ & 70.4 & 0.55 & 9.73 & 4.68 & 0.05 & 0.88 & 0.96 & 1.72 & 2.04 & 6.77 & 7.27 & 36.4 \\
\hline $52-2,22-27$ & 68.5 & 0.46 & 9.57 & 4.16 & 0.06 & 1.37 & 2.23 & 1.58 & 2.64 & 9.27 & 7.15 & 35.0 \\
\hline $56-2,35-39$ & 67.6 & 0.60 & 11.39 & 5.22 & 0.06 & 0.58 & 0.89 & 2.00 & 2.97 & 8.06 & 5.93 & 27.7 \\
\hline $64-2,125-127$ & 69.6 & 0.41 & 8.75 & 4.24 & 0.06 & 1.83 & 1.40 & 1.17 & 3.80 & 8.70 & 7.96 & 39.0 \\
\hline $70-2,90-94$ & 67.0 & 0.53 & 11.09 & 5.22 & 0.05 & 2.61 & 0.62 & 1.68 & 2.41 & 8.39 & 6.04 & 28.2 \\
\hline $80-2,124-126$ & 69.5 & 0.41 & 9.02 & 3.87 & 0.05 & 2.33 & 0.73 & 1.32 & 2.32 & 9.72 & 7.71 & 38.0 \\
\hline $82-2,100-102$ & 64.7 & 0.59 & 11.58 & 5.78 & 0.07 & 1.46 & 2.27 & 1.59 & 2.65 & 8.73 & 5.59 & 24.2 \\
\hline $438 \mathrm{~B}-12-2,44-45$ & 68.5 & 0.48 & 8.55 & 4.38 & 0.05 & 1.12 & 1.80 & 1.24 & 3.67 & 10.20 & 8.01 & 38.6 \\
\hline $18-2,88-93$ & 63.4 & 0.64 & 13.48 & 5.96 & 0.06 & 3.17 & 0.90 & 2.45 & 2.02 & 8.90 & 4.70 & 16.2 \\
\hline $20-2,75-78$ & 65.7 & 0.53 & 12.56 & 7.34 & 0.04 & 1.71 & 1.36 & 2.48 & 2.29 & 6.03 & 5.23 & 21.7 \\
\hline
\end{tabular}


TABLE 1 - Continued

\begin{tabular}{|c|c|c|c|c|c|c|c|c|c|c|c|c|}
\hline $\begin{array}{c}\text { Sample } \\
\text { (interval in } \mathrm{cm} \text { ) }\end{array}$ & $\mathrm{SiO}_{2}$ & $\mathrm{TiO}_{2}$ & $\mathrm{Al}_{2} \mathrm{O}_{3}$ & $\mathrm{Fe}_{2} \mathrm{O}_{3} \mathrm{a}$ & $\mathrm{MnO}$ & $\mathrm{MgO}$ & $\mathrm{CaO}$ & $\mathrm{K}_{2} \mathrm{O}$ & $\mathrm{Na}_{2} \mathrm{O}$ & L.o.i. & $\frac{\mathrm{SiO}_{2}}{\mathrm{Al}_{2} \mathrm{O}_{3}}$ & $\begin{array}{l}\text { "Excess" } \\
\mathrm{SiO}_{2}{ }^{\mathrm{b}}\end{array}$ \\
\hline $439-10-2,106-109$ & 63.9 & 0.54 & 11.33 & 5.49 & 0.04 & 2.15 & 0.80 & 1.79 & 3.56 & 10.37 & 5.64 & 24.3 \\
\hline $12-1,146-148$ & 66.6 & 0.61 & 14.70 & 3.93 & 0.04 & 1.79 & 2.06 & 2.12 & 2.32 & 5.72 & 4.53 & 15.1 \\
\hline $18-2,74-76$ & 64.9 & 0.60 & 13.73 & 4.78 & 0.05 & 1.63 & 1.29 & 2.19 & 2.35 & 8.47 & 4.73 & 16.9 \\
\hline $26-1,73-75$ & 66.1 & 0.54 & 14.94 & 4.40 & 0.05 & 1.77 & 1.92 & 2.51 & 2.50 & 5.19 & 4.43 & 13.9 \\
\hline $28-1,87-90$ & 66.6 & 0.48 & 15.48 & 3.86 & 0.04 & 1.30 & 3.37 & 1.98 & 3.14 & 3.68 & 4.31 & 12.5 \\
\hline $38-1,32-36$ & 62.9 & 0.69 & 16.10 & 6.62 & 0.05 & 2.44 & 0.57 & 2.83 & 1.91 & 5.57 & 3.90 & 6.4 \\
\hline $39-1,50-52$ & 61.0 & 0.74 & 17.00 & 6.95 & 0.06 & 2.47 & 0.54 & 3.28 & 2.05 & 5.27 & 3.59 & 1.5 \\
\hline $440-4-1,28-32$ & 59.3 & 0.75 & 12.36 & 6.85 & 0.08 & 1.02 & 1.91 & 2.18 & 3.56 & 10.90 & 4.82 & 16.0 \\
\hline $440 \mathrm{~A}-2-1,36-40$ & 59.6 & 0.61 & 9.76 & 5.52 & 0.07 & 1.12 & 2.83 & 1.44 & 3.45 & 14.30 & 6.11 & 25.4 \\
\hline $6-1,124-128$ & 64.0 & 0.46 & 9.40 & 4.12 & 0.05 & 2.16 & 2.41 & 1.50 & 2.85 & 19.02 & 6.81 & 31.1 \\
\hline $440 B-6-1,73-76$ & 61.2 & 0.63 & 12.58 & 5.74 & 0.07 & 1.72 & 1.25 & 2.04 & 2.94 & 11.15 & 4.86 & 17.2 \\
\hline $12-1,73-77$ & 61.1 & 0.60 & 12.75 & 4.96 & 0.06 & 2.29 & 1.40 & 1.96 & 3.26 & 10.90 & 4.79 & 16.5 \\
\hline $16-1,127-131$ & 64.8 & 0.46 & 11.02 & 4.41 & 0.06 & 2.40 & 1.26 & 1.91 & 3.83 & 9.89 & 5.88 & 26.2 \\
\hline $24-1,116-120$ & 67.0 & 0.44 & 8.99 & 3.98 & 0.06 & 1.33 & 0.96 & 1.36 & 2.81 & 12.45 & 7.45 & 35.5 \\
\hline $32-1,42-45$ & 71.9 & 0.38 & 7.52 & 2.99 & 0.06 & 1.35 & 1.06 & 1.23 & 2.11 & 10.70 & 9.57 & 45.6 \\
\hline $40-1,77-80$ & 70.4 & 0.40 & 7.40 & 3.64 & 0.05 & 1.36 & 0.64 & 1.13 & 2.10 & 12.38 & 9.52 & 44.6 \\
\hline $50-1,117-121$ & 69.6 & 0.34 & 7.10 & 3.30 & 0.05 & 1.54 & 2.32 & 1.09 & 1.89 & 12.15 & 9.80 & 44.8 \\
\hline $56-1,68-70$ & 71.7 & 0.39 & 8.56 & 3.35 & 0.04 & 0.90 & 0.83 & 1.33 & 2.69 & 10.25 & 8.37 & 41.7 \\
\hline $66-1,32-34$ & 70.0 & 0.35 & 7.83 & 3.37 & 0.05 & 1.36 & 1.67 & 1.29 & 1.65 & 11.90 & 8.94 & 42.6 \\
\hline $441-8-1,104-108$ & 67.8 & 0.43 & 8.82 & 4.09 & 0.06 & 0.99 & 0.94 & 1.46 & 2.68 & 11.82 & 7.69 & 36.9 \\
\hline $441 \mathrm{~A}-10-1,47-49$ & 61.3 & 0.52 & 12.24 & 5.47 & 0.93 & 2.94 & 0.84 & 2.18 & 1.96 & 11.22 & 5.00 & 18.5 \\
\hline $441 \mathrm{~B}-2-1,91-93$ & 63.6 & 0.54 & 12.55 & 5.12 & 0.13 & 1.96 & 0.98 & 2.39 & 2.69 & 10.00 & 5.07 & 19.7 \\
\hline
\end{tabular}

${ }^{\mathrm{a}}$ Total $\mathrm{Fe}$ as $\mathrm{Fe}_{2} \mathrm{O}_{3}$.
${ }^{\text {b }}$ "Excess" $\mathrm{SiO}_{2}=$ total $\mathrm{SiO}_{2}-\left(3.5 \times \mathrm{Al}_{2} \mathrm{O}_{3}\right)$.
${ }^{\mathrm{c}}$ Contaminated with rust from drilling pipe.

TABLE 2

Bulk Analyses (wet chemistry) of the Leg 56 Sediments

\begin{tabular}{|c|c|c|c|c|c|c|c|c|c|c|c|c|c|c|}
\hline $\begin{array}{c}\text { Sample } \\
\text { (in terval in } \mathrm{cm} \text { ) }\end{array}$ & $\mathrm{SiO}_{2}$ & $\mathrm{TiO}_{2}$ & $\mathrm{Al}_{2} \mathrm{O}_{3}$ & $\mathrm{Fe}_{2} \mathrm{O}_{3}$ & $\mathrm{FeO}$ & $\mathrm{MnO}$ & $\mathrm{MgO}$ & $\mathrm{CaO}$ & $\mathrm{K}_{2} \mathrm{O}$ & $\mathrm{Na}_{2} \mathrm{O}$ & L.o.i. & Total & $\frac{\mathrm{SiO}_{2}}{\mathrm{Al}_{2} \mathrm{O}_{3}}$ & $\begin{array}{l}\text { "Excess" } \\
\mathrm{SiO}_{2}{ }^{\mathrm{a}}\end{array}$ \\
\hline $434-1-2,30-35$ & 58.88 & 0.48 & 10.34 & 3.71 & 1.80 & 0.08 & 1.20 & 1.31 & 2.14 & 2.88 & 17.08 & 99.90 & 5.69 & 22.69 \\
\hline $7-1,120-124$ & 63.28 & 0.43 & 10.06 & 2.69 & 1.80 & 0.07 & 0.66 & 1.44 & 1.86 & 2.15 & 15.54 & 99.90 & 6.29 & 28.07 \\
\hline $12-1,85-89$ & 64.96 & 0.46 & 8.77 & 3.12 & 2.16 & 0.17 & 0.74 & 0.87 & 1.65 & 1.43 & 15.74 & 99.90 & 7.41 & 34.24 \\
\hline $21-1,40-44$ & 63.70 & 0.41 & 9.42 & 2.75 & 1.70 & 0.05 & 0.46 & 0.81 & 1.90 & 2.08 & 16.76 & 100.00 & 6.76 & 30.73 \\
\hline $435-1-1,54-58$ & 56.96 & 0.60 & 12.25 & 3.93 & 2.67 & 0.08 & 1.84 & 2.69 & 2.03 & 3.53 & 13.44 & 100.00 & 4.65 & 14.10 \\
\hline $436-1-3,20-25$ & 55.14 & 0.61 & 13.04 & 3.87 & 2.06 & 0.07 & 1.70 & 2.18 & 2.50 & 3.45 & 15.25 & 99.99 & 4.23 & 9.50 \\
\hline $9-2,120-125$ & 57.97 & 0.43 & 10.77 & 3.12 & 1.64 & 0.06 & 0.78 & 1.21 & 2.59 & 3.24 & 18.10 & 99.80 & 5.38 & 20.27 \\
\hline $15-4,60-64$ & 57.27 & 0.58 & 13.07 & 2.92 & 1.67 & 0.07 & 1.59 & 1.85 & 2.73 & 3.41 & 13.84 & 99.90 & 4.38 & 11.50 \\
\hline $27-3,60-64$ & 61.67 & 0.47 & 11.61 & 2.24 & 2.06 & 0.06 & 1.10 & 1.13 & 2.64 & 3.00 & 14.92 & 99.90 & 5.31 & 21.03 \\
\hline $31-1,33-37$ & 59.67 & 0.41 & 12.99 & 4.13 & 1.34 & 0.21 & 0.55 & 1.17 & 3.28 & 2.68 & 13.56 & 99.90 & 4.59 & 14.21 \\
\hline $34-3,60-64$ & 58.46 & 0.48 & 13.18 & 4.49 & 1.64 & 0.20 & 0.55 & 1.21 & 3.13 & 2.42 & 14.22 & 99.97 & 4.44 & 12.33 \\
\hline $36-3,50-54$ & 52.95 & 0.65 & 14.91 & 5.31 & 1.44 & 0.46 & 1.30 & 0.68 & 3.20 & 2.22 & 16.73 & 99.90 & 3.55 & 0.77 \\
\hline $38-6,76-80$ & 46.41 & 0.69 & 16.28 & 7.22 & 0.62 & 3.67 & 2.16 & 0.88 & 2.91 & 2.05 & 17.01 & 99.90 & 2.85 & - \\
\hline $38-6,90-94$ & 54.68 & 0.58 & 13.57 & 5.58 & 9.20 & 0.76 & 0.96 & 0.74 & 2.87 & 2.64 & 16.60 & 99.90 & 4.03 & 7.18 \\
\hline $39-2,26-30$ & 49.49 & 0.65 & 14.46 & 7.28 & 0.82 & 1.01 & 2.52 & 1.07 & 2.32 & 1.92 & 18.30 & 99.80 & 3.42 & - \\
\hline $40-4,54-58$ & 45.80 & 0.66 & 16.63 & 6.48 & 1.03 & 4.39 & 2.89 & 0.58 & 4.13 & 1.63 & 5.67 & 99.90 & 2.75 & - \\
\hline $41-1,10-12$ & 45.58 & 0.96 & 14.10 & 7.13 & 0.82 & 3.18 & 3.09 & 3.57 & 3.13 & 1.99 & 16.48 & 100.00 & 3.23 & - \\
\hline $41-1,34-35$ & 48.58 & 0.53 & 11.10 & 10.42 & 1.54 & 0.09 & 3.23 & 1.06 & 3.34 & 1.43 & 18.51 & 99.90 & 4.38 & 9.73 \\
\hline
\end{tabular}

a"Excess" $\mathrm{SiO}_{2}=\mathrm{SiO}_{2}-\left(3.5 \times \mathrm{Al}_{2} \mathrm{O}_{3}\right)$.

the $\mathrm{SiO}_{2} / \mathrm{Al}_{2} \mathrm{O}_{3}$ ratio (3.9 and 3.6), as well as the calculated "excess" silica (6.4 and $1.5 \%)$, are very low because of high $\mathrm{Al}_{2} \mathrm{O}_{3}$ content.

The transition from the hemipelagic section to pelagic clay at Site 436 is marked by gradual downhole decrease in total silica, as well as decrease in "excess" and "amorphous" silica which occurs in radiolarian claystone of unit III. The pelagic clay itself contains 46 to 51 per cent total silica. The $\mathrm{SiO}_{2} / \mathrm{Al}_{2} \mathrm{O}_{3}$ ratio ranges from 2.7 to 3.2 , being much lower than values for the "normal" terrigenous clay matrix. A sample of yellowishbrown, zeolitic clay from Core 436-41 is somewhat enriched in silica with respect to aluminum $\left(\mathrm{SiO}_{2} / \mathrm{Al}_{2} \mathrm{O}_{3}=\right.$ 4.4). Dark-brown chert from Core $436-42$ contains 87 per cent total silica, 79.6 per cent of which is in excess to the clay matrix; the $\mathrm{SiO}_{2} / \mathrm{Al}_{2} \mathrm{O}_{3}$ ratio is 41.4 . 


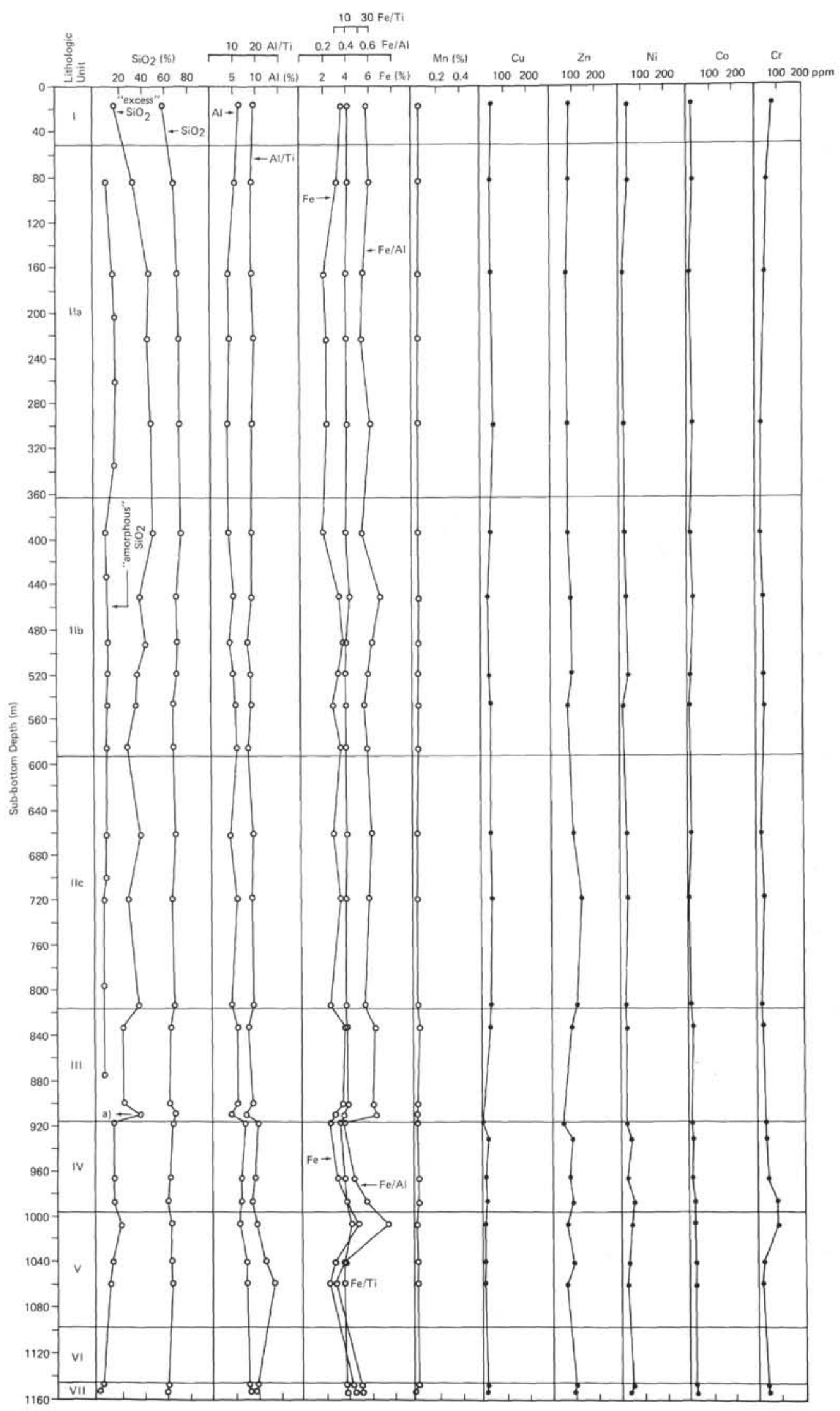

Figure 2. Downhole variations in concentrations of elements and their ratios at Sites 438 and 439. For explanations of symbols, see Figure 3. 


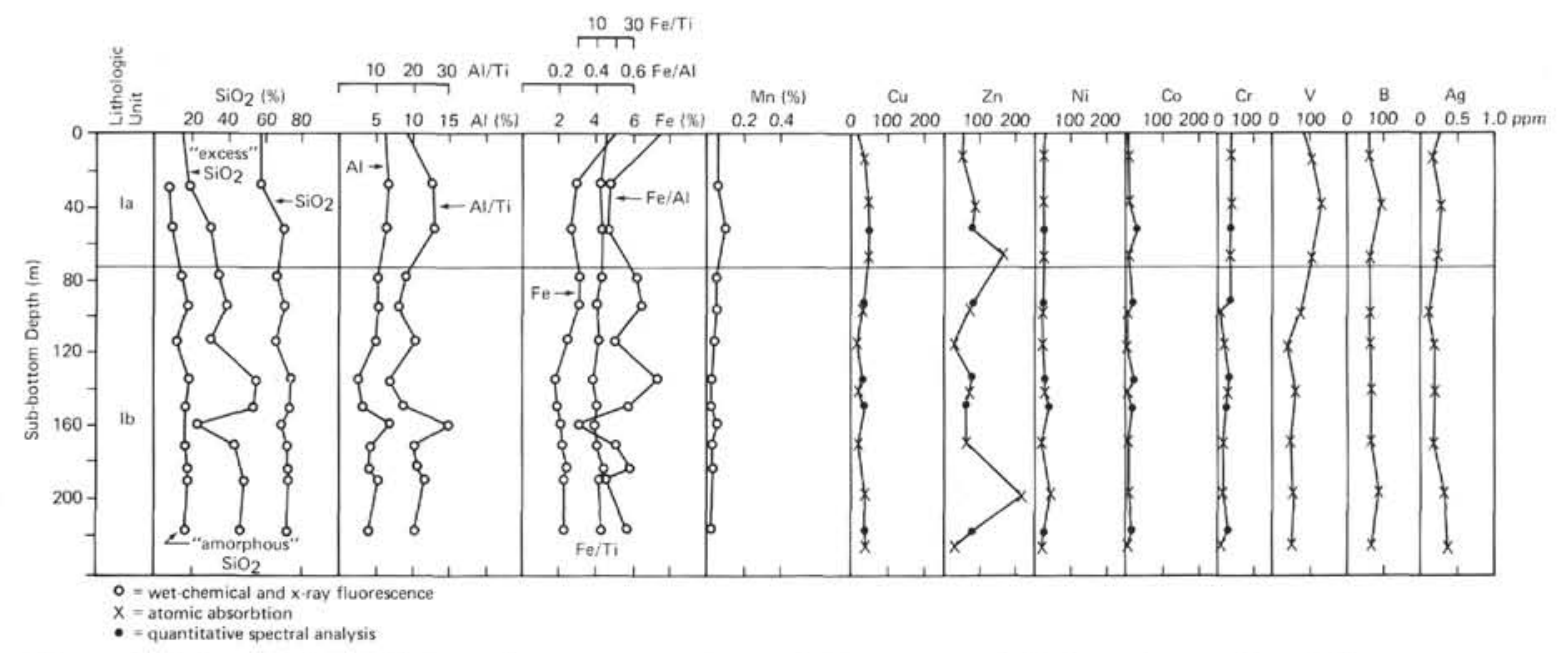

Figure 3. Downhole variations in concentrations of elements and their ratios at Site 435.

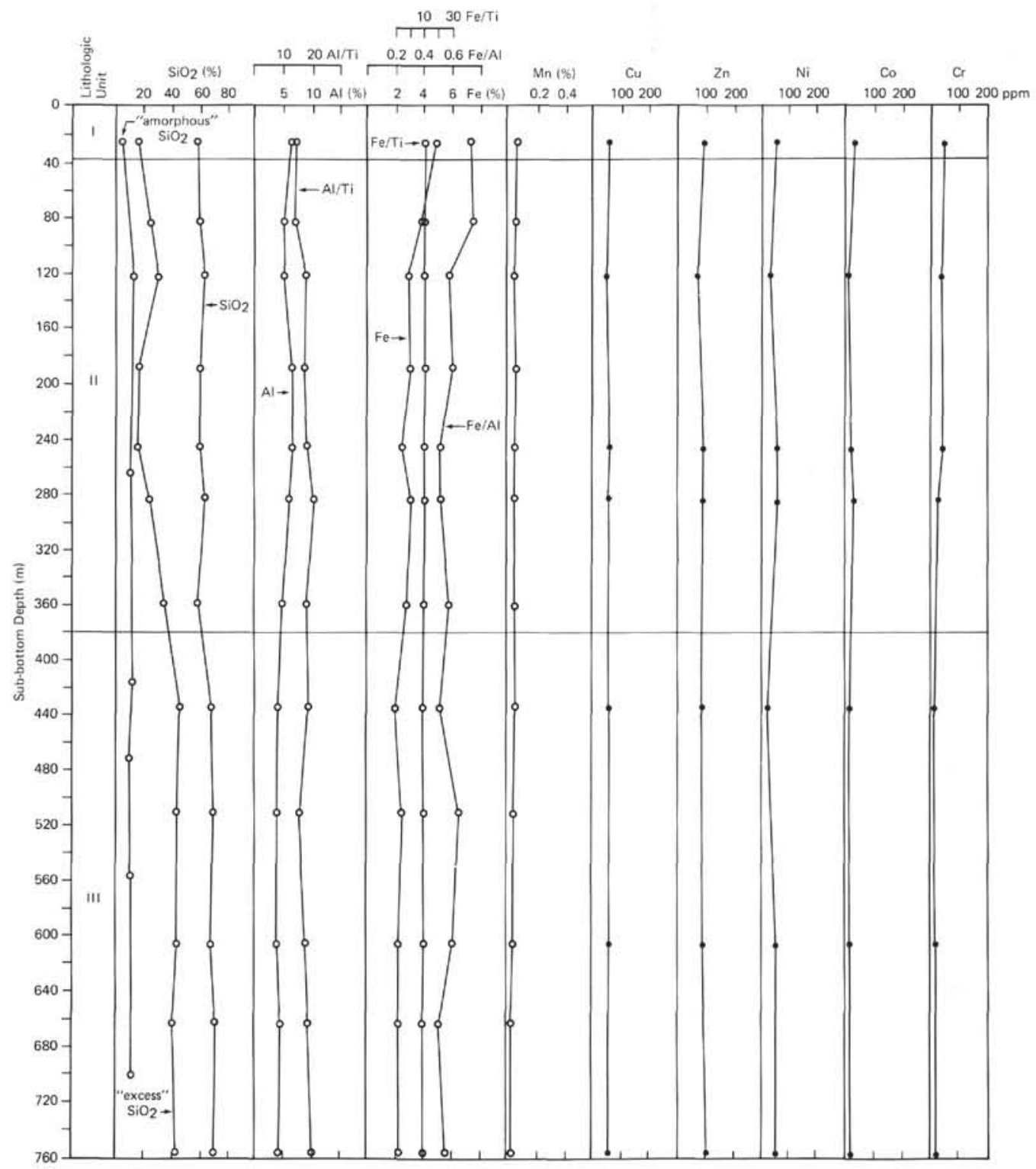

Figure 4. Downhole variations in concentrations of elements and their ratios at Site 440. For explanations of symbols, see Figure 3. 


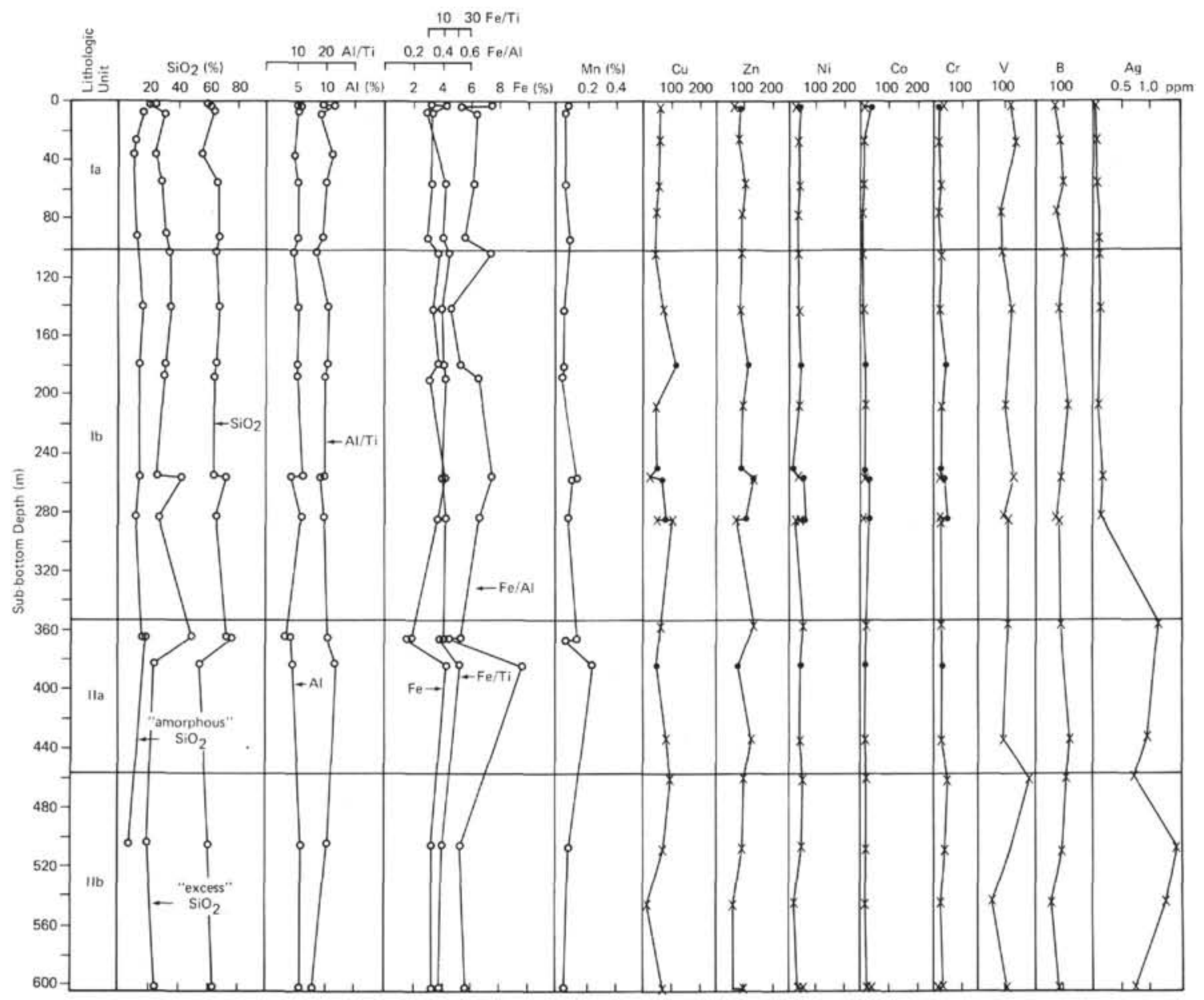

Figure 5. Downhole variations in concentrations of elements and their ratios at Site 434. For explanations of symbols, see Figure 3.

\section{ALUMINUM AND TITANIUM}

Both aluminum and titanium are closely associated with particulate (terrigenous and volcaniclastic) material. Their migration in solutions and participation in biogenic cycles are quantitatively negligible except for pelagic environments of very slow accumulation, where dissolved forms of the elements may be somewhat more significant. Biogenic silica serves as their "dilutant," showing negative correlation with $\mathrm{Al}$ and $\mathrm{Ti}$ concentrations.

We detected $\mathrm{Al}_{2} \mathrm{O}_{3}$ and $\mathrm{TiO}_{2}$ content by X-ray fluorescence and chemical bulk analyses (Tables 1 and 2 ). The concentrations of both elements are uniformly low throughout the Neogene to Quaternary hemipelagic sections along the Japan Trench transect, as compared with average shales, sedimentary rocks, or Holocene hemipelagic clay, obviously because of "dilution" by biogenic silica. The titanium concentration (Table 4) ranges from 0.17 to 0.45 per cent, but a great majority of samples fall within the narrow range 0.2 to 0.3 per cent. The aluminum content ranges from 2.5 to 7.9 per cent, but medium values from 4 to 7 per cent apparently predominate over extreme values. Both elements show a negative correlation with total and "excess"silica.
The aluminum/titanium ratio is shown to be indicative of non-biogenic particulate matter in ocean sediments. It appears to be about constant in most hemipelagic and pelagic sediments which do not contain much volcaniclastic material.

In the Japan Trench hemipelagic sediments, the aluminum/titanium ratio ranges from 13.7 to 32.2 (Table 4). Common values are in the range 18 to 22 , and they approximately correspond with those for "average shale" (17.5; Boström, 1976), for ''average sedimentary rocks" (22.1; calculated from Vinogradov's data, 1962) and for the modern river load of the world (20.8; after Gordeev and Lisitzin, 1979). It differs markedly from the ratio in basaltic material, where the values are commonly below 10 .

The figures higher than 22 are likely caused by acidic vitric ash and plagioclase; island-arc vitric tephra is characterized by ratios greater than 25 . In vitric tephra layers from the western North Pacific (Repechka, 1974), for example, the average $\mathrm{Al} / \mathrm{Ti}$ ratio is 34.6 (35 samples). We obtained even higher values in Indian Ocean ash layers.

The ratio tends to be lower in some highly siliceous layers; however, the $\mathrm{Al} / \mathrm{Ti}$ curves in Figures 2 to 6 show both direct and reverse trends with respect to $\mathrm{SiO}_{2}$, sug- 


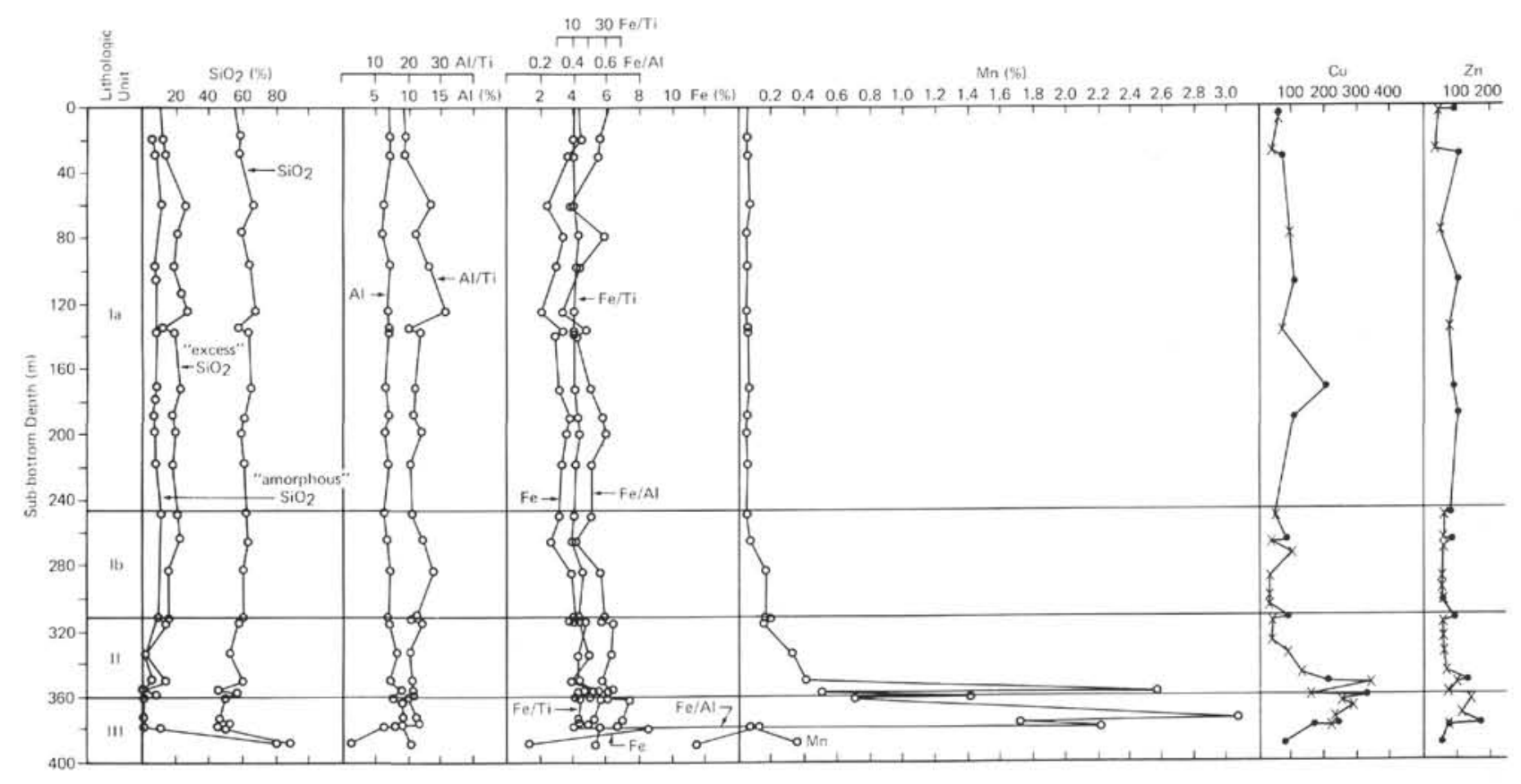

Figure 6. Downhole variations in concentrations of elements and their ratios at Site 436. For explanations of symbols, see Figure 3.

gesting the absence of any certain relationship between the two values.

The lower-Miocene turbidites and upper-Oligocene sandstones at Sites 438 and 439 are somewhat enriched in both aluminum and titanium as compared with the hemipelagic diatomaceous mud: $\mathrm{Ti}$ ranges from 0.29 to 0.38 per cent, and $\mathrm{Al}$ from 6.6 to 8.2 per cent. The additional amounts of the elements are likely associated with clastic terrigenous material. The $\mathrm{Al} / \mathrm{Ti}$ ratio ranges from 18.6 to 28.4 . The higher values are indicative of high-aluminum and low-titanium clastic material, which consists of feldspars and acidic rock fragments.

The aluminum and titanium contents in the pelagic clay from Site 436 (unit III) are also somewhat increased (up to $8.8 \%$ of $\mathrm{Al}$ and up to $0.58 \%$ of $\mathrm{Ti}$ ), and the $\mathrm{Al} / \mathrm{Ti}$ ratio is similar to that for hemipelagic sediments ( 17.3 to 22.4) except for one sample from Core 436-41, where it decreases to 12.9. A chert sample shows a common value of the ratio (20.5).

\section{IRON AND MANGANESE}

The two transition metals iron and manganese occur in sediments both in association with stable minerals of particulate matter and as "hydrogenous" forms which are sensitive to changing oxidation potential. In the reducing environment generated in hemipelagic sediments during early diagenesis, soluble $\mathrm{Mn}^{2+}$ and $\mathrm{Fe}^{2+}$ pass from solids to interstitial water and then migrate upward to the redox boundary. The migration of $\mathrm{Fe}^{2+}$ is restricted by sulfide (pyrite) precipitation, whereas $\mathrm{Mn}^{2+}$ may be removed from reduced sediments almost entirely.

Biogenic silica, as well as acidic volcanic glass, tends to "dilute" the total $\mathrm{Fe}$ and $\mathrm{Mn}$ concentrations in sediments. To eliminate their influence, we used ratios of $\mathrm{Fe}$ and $\mathrm{Mn}$ to $\mathrm{Al}$ and $\mathrm{Ti}$. Boström (1976) proposed to define non-terrigenous (or "authigenic") iron as "authigenic" $\mathrm{Fe}=$ total $\mathrm{Fe}-(0.6 \times \mathrm{Al})$, but we could not apply this formula to the Japan Trench sediments, because they commonly contain less iron than $0.6 \times \mathrm{Al}$. Nevertheless, authigenic Fe (pyrite) was found in these sediments.

The bulk X-ray fluorescence analyses and several chemical analyses (Tables 1 and 2 ) indicate that the absolute concentrations of $\mathrm{Fe}$ in the Japan Trench Neogene to Quaternary hemipelagic sediments are lower than the averages for terrigenous matter or for hemipelagic clay. The iron content ranges from 1.7 to 4.9 per cent, but values between 2.5 and 4 per cent predominate. Iron content shows an inverse relation to "excess" $\mathrm{SiO}_{2}$ (Figures 2-6) suggesting dilution of iron by biogenic silica. The lowest concentrations of $\mathrm{Fe}$ (less than $2.5 \%$ ) characterize the highly siliceous early-Pliocene sediments at Sites 438 and 435 , whereas Quaternary and late-Pliocene sediments at these sites contain somewhat more iron, as do late-Miocene deposits at Site 438 (values more than $3 \%$ predominate). Quaternary and late-Miocene sediments at other sites are also relatively enriched in iron as compared with Pliocene (particularly early-Pliocene) sediments.

$\mathrm{The} \mathrm{Fe} / \mathrm{Al}$ ratio in the hemipelagic sediments ranges from 0.3 to 1.0 , but values less than 0.4 are seldom found and correspond only to ash layers. High values (more than 0.7 ) which indicate some "excess" iron (with respect to "normal" terrigenous matter), occur sporadically at Sites 434, 435, and 440 . Authigenic pyrite may be responsible for the increase. A single sample from Section 434-5-1, which contains as much as 
TABLE 3

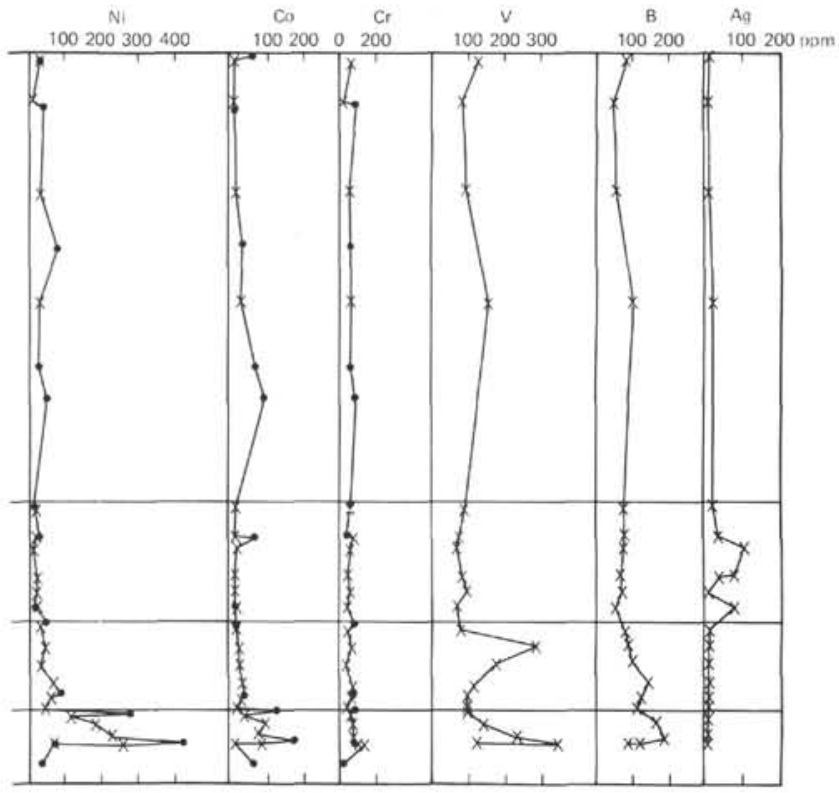

Figure 6. Continued.

12.0 per cent iron ( $\mathrm{Fe} / \mathrm{Al}$ ratio 3.6 ), appeared to be contaminated by metallic shavings and rust, likely from the drill pipe.

The $\mathrm{Fe} / \mathrm{Al}$ ratio is commonly inversely related to the $\mathrm{Al} / \mathrm{Ti}$ ratio (Figures 2-6), and it tends to parallel the $\mathrm{Fe}$ distribution; the variation range of the $\mathrm{Fe} / \mathrm{Al}$ ratio is greater because of the additive influences of both $\mathrm{Fe}$ and Al percentages.

The $\mathrm{Fe} / \mathrm{Ti}$ ratio is almost constant throughout the hemipelagic sections at all sites. An apparent correlation between iron and titanium (Figure 7) confirms this. We suggest that these elements are genetically related and associated mainly with clastic (particulate) material. The approximate mean value of the $\mathrm{Fe} / \mathrm{Ti}$ ratio (10.6) shown on Figure 7 is close to the average value for Holocene hemipelagic sediments of the western North Pacific (10.1; Skornyakova, 1976) for the terrigenous material input to the world ocean (10.2; Boström, 1976), and for the suspended matter of rivers (12.8; Gordeev and Lisitzin, 1979). The dots below the mean line are indicative of some "excess" $\mathrm{Fe}$, which is likely that of authigenic pyrite. The $\mathrm{Fe} / \mathrm{Ti}$ ratio increases slightly in several samples at Sites 434, 435, and 436, along with a more significant increase in the $\mathrm{Fe} / \mathrm{Al}$ ratio, thus pointing to authigenic iron as well. But the relative proportion of non-terrigenous iron is likely very small, except for one contaminated sample from Site 434 , previously mentioned.

Manganese content in the hemipelagic sediments is evenly low (less than $0.1 \%$ ) throughout, except for several samples from the lower Pliocene at Site 434, where it increases to 0.25 per cent, likely because of authigenic rhodochrosite. The $\mathrm{Mn} / \mathrm{Al}$ ratio in a great majority of samples is about 0.01 , the value which Boström (1976) has shown as an average for terrigenous material, and the figure which Gordeev and Lisitzin
"Amorphous" Silica in Sediments of Legs 56 and 57, as
Determined by Sodium Carbonate Extraction

\begin{tabular}{|c|c|c|c|}
\hline $\begin{array}{c}\text { Sample } \\
\text { (interval in } \mathrm{cm} \text { ) }\end{array}$ & $\begin{array}{l}\text { "Amor- } \\
\text { phous" } \\
\mathrm{SiO}_{2} \\
\text { (wt. \%) }\end{array}$ & $\begin{array}{c}\text { Sample } \\
\text { (interval in } \mathrm{cm} \text { ) }\end{array}$ & $\begin{array}{c}\text { "Amor- } \\
\text { phous" } \\
\mathrm{SiO}_{2} \\
\text { (wt. \%) }\end{array}$ \\
\hline $434-2-1,89-93$ & 14.70 & $436-21-1,50-54$ & 5.63 \\
\hline $4-1,110-116$ & 10.43 & $24-1,80-84$ & 7.26 \\
\hline $5-1,130-134$ & 9.23 & $27-2,74-78$ & 10.00 \\
\hline $11, \mathrm{CC}, 5-9$ & 10.66 & $32-2,52-56$ & 5.97 \\
\hline $16-1,78-82$ & 15.56 & $34-1,85-87$ & 8.78 \\
\hline $20-1,54-58$ & 12.66 & $34-1,60-64$ & 7.96 \\
\hline $37-1,90-94$ & 8.43 & $38-1,96-100$ & 4.55 \\
\hline $28-2,26-28$ & 14.30 & $40-6,48-52$ & 0.96 \\
\hline $30-1,71-74$ & 14.55 & & \\
\hline $31-1,47-51$ & 11.20 & $438-10-2,112-116$ & 9.70 \\
\hline $434 \mathrm{~B}-9-2,48-51$ & 14.82 & $438 \mathrm{~A}-6-2,84-88$ & 16.41 \\
\hline $9-2,110-114$ & 15.54 & $12-2,33-37$ & 13.81 \\
\hline \multirow[t]{2}{*}{$24-1,24-30$} & 7.26 & $16-2,60-62$ & 15.76 \\
\hline & & $22-2,90-94$ & 14.57 \\
\hline $435-4-1,102-106$ & 8.40 & $26-2,39-43$ & 17.05 \\
\hline $6-4,90-94$ & 9.34 & $30-2,44-48$ & 14.99 \\
\hline $7-5,28-32$ & 4.72 & $36-2,50-54$ & 7.34 \\
\hline $9-3,50-52$ & 14.68 & $40-2,106-110$ & 8.87 \\
\hline $11-1,64-67$ & 18.33 & $46-2,8-12$ & 9.36 \\
\hline $12-2,42-48$ & 18.41 & $48-2,30-32$ & 8.60 \\
\hline $13-1,90-94$ & 11.68 & $50-2,118-122$ & 8.27 \\
\hline $15-3,31-35$ & 18.16 & $52-2,22-27$ & 7.63 \\
\hline $435 A-3-1,38-42$ & 16.89 & $56-2,35-39$ & 8.15 \\
\hline $3-4,28-32$ & 16.02 & $64-2,125-127$ & 9.28 \\
\hline $4-3,50-54$ & 16.58 & $78-2,87-89$ & 6.43 \\
\hline $5-5,49-52$ & 16.76 & $438 \mathrm{~B}-6-2,126-130$ & 6.78 \\
\hline $6-2,58-62$ & 18.41 & & \\
\hline $9-2,100-104$ & 17.28 & $440-4-1,28-32$ & 5.77 \\
\hline \multirow[t]{2}{*}{$10-1,53-56$} & 18.78 & $440 \mathrm{~A}-6-1,124-128$ & 13.98 \\
\hline & & $440 B-14-1,53-57$ & 12.53 \\
\hline $436-1-2,120-124$ & 8.18 & $30-1,110-114$ & 13.02 \\
\hline $3-1,100-104$ & 4.65 & $36-1,38-40$ & 12.30 \\
\hline $4-4,88-92$ & 6.04 & $45-1,76-81$ & 11.76 \\
\hline $7-4,50-54$ & 9.62 & $60-1,60-64$ & 10.92 \\
\hline $11-3,90-94$ & 6.19 & & \\
\hline $12-3,36-40$ & 7.06 & $441-2-1,73-77$ & 7.65 \\
\hline $15-5,60-64$ & 6.37 & $8-1,104-108$ & 13.15 \\
\hline $19-1,94-98$ & 7.59 & $441 \mathrm{~A}-8-1,50-54$ & 11.56 \\
\hline $20-1,37-39$ & 7.11 & $441 \mathrm{~B}-41-1,140-143$ & 13.25 \\
\hline
\end{tabular}

(1979) consider average for river loads. However, average ratios in North Pacific sediments are markedly higher (0.06; Boström, 1976), and in many cases our analyses show ratios below 0.01 (Table 4).

$\mathrm{The} \mathrm{Mn} / \mathrm{Ti}$ ratio is also low, commonly about 0.15 to 0.25 (Table 4), close to Boström's (1976) average (0.18) for terrigenous material and Gordeev and Lisitzin's (1979) average (0.27) for river loads, but less than that for hemipelagic diatomaceous sediments $(0.67$; Skornyakova, 1976). Variations in the $\mathrm{Mn} / \mathrm{Fe}$ ratio, which in most samples ranges from 0.013 to 0.026 , are rather insignificant, at least on the low-sensitivity level of our manganese determinations.

Therefore, the manganese content in the Japan Trench sediments both in absolute percentages and relative to $\mathrm{Al}, \mathrm{Ti}$, and $\mathrm{Fe}$, is equal to or somewhat lower than the aforementioned averages for hemipelagic sediments or for terrigenous material.

The lower-Miocene turbidites and upper-Oligocene sandstones drilled at Sites 438 and 439 do not show any 
TABLE 4

Concentrations (wt. \%) and Ratios of $\mathrm{Ti}, \mathrm{Al}, \mathrm{Fe}$, and $\mathrm{Mn}$ for Sediments of Legs 56 and 57

\begin{tabular}{|c|c|c|c|c|c|c|c|c|c|c|}
\hline $\begin{array}{c}\text { Sample } \\
\text { (interval in } \mathrm{cm} \text { ) }\end{array}$ & $\mathrm{Ti}$ & Al & $\mathrm{Fe}$ & $\mathrm{Mn}$ & $\frac{\mathrm{Al}}{\mathrm{Ti}}$ & $\frac{\mathrm{Fe}}{\mathrm{Ti}}$ & $\frac{\mathrm{Fe}}{\mathrm{Al}}$ & $\frac{M n}{A l}$ & $\frac{\mathrm{Mn}}{\mathrm{Fe}}$ & $\frac{\mathrm{Mn}}{\mathrm{Ti}}$ \\
\hline $4-1-2,30-35$ & 0.29 & 5.47 & 3.99 & 0.06 & 18.9 & 13.8 & 0.73 & 0.01 & 0.02 & 0.21 \\
\hline $1-2,64-69$ & 0.27 & 6.19 & 3.28 & 0.06 & 22.9 & 12 & 0.53 & 0.01 & 0.02 & 0.23 \\
\hline $2-1,89-93$ & 0.29 & 5.31 & 3.39 & 0.05 & 18.4 & 11.8 & 0.64 & 0.01 & 0.01 & 0.16 \\
\hline $5-1,130-134$ & 0.21 & 4.70 & 12.0 & 0.18 & 22.4 & 57.1 & 3.60 & 0.04 & 0.02 & 0.85 \\
\hline $7-1,120-124$ & 0.29 & 5.32 & 3.28 & 0.05 & 20.5 & 12.6 & 0.62 & 0.01 & 0.02 & 0.17 \\
\hline 11, CC, 5-9 & 0.28 & 5.34 & 2.99 & 0.08 & 19.4 & 10.8 & 0.56 & & & 0.28 \\
\hline $12-1,85-89$ & 0.28 & 4.64 & 3.86 & 0.13 & 16.6 & 13.8 & 0.83 & 0.03 & 0.03 & 0.46 \\
\hline $16-1,78-82$ & 0.25 & 3.34 & 2.54 & 0.05 & 21.7 & 10.3 & 0.48 & 0.01 & 0.02 & 0.22 \\
\hline $20-1,54-58$ & 0.25 & 5.35 & 2.86 & 0.05 & 21.8 & 11.6 & 0 & 0.01 & 0.02 & 0.19 \\
\hline $21-1,40-44$ & 0.25 & 4.98 & 3.2 & 0.04 & 19.9 & 13.0 & 0.65 & 0.01 & 0.01 & 0.16 \\
\hline $28-1,100-102$ & 0.29 & 5.82 & 4.39 & 0.13 & 19.8 & 14.9 & 0.75 & 0.02 & 0.03 & 0.45 \\
\hline $28-2,26-$ & 0.23 & 4.38 & 2. & 0.10 & 19.8 & 10.8 & 0.56 & 0.02 & & 0.44 \\
\hline $31-1,47-51$ & 0.28 & 5.82 & 3.88 & 0.08 & 20.6 & 13.8 & 0.67 & 0.01 & 0.02 & 0.27 \\
\hline $434 \mathrm{~B}-9-2,48-51$ & 0.17 & 3.61 & 1.94 & 0.14 & 21.5 & 11.6 & 0.54 & 0.04 & 0.07 & 0.82 \\
\hline $9-2,110-11$ & 0 & 3.82 & 1.74 & 0.04 & 21.2 & 9.7 & 0.46 & 0.01 & 0.02 & 0.22 \\
\hline $11-1,100-$ & 0.19 & 4.59 & 4.45 & 0.26 & 23.9 & 23.2 & 0.97 & 0.06 & 0.06 & 1.33 \\
\hline $13, \mathrm{CCa}$ & 0.07 & 3.28 & 1.34 & 0.37 & 49.8 & 20 & 0.41 & 0.11 & 0. & 5.64 \\
\hline $24-1,24-30$ & 0.30 & 6.22 & 3.38 & 0.09 & 20.7 & 11.2 & 0.54 & 0.02 & 0.03 & 0.31 \\
\hline $34-1,8$ & 0.36 & 5.92 & 3.50 & 0.06 & 16.5 & 9.7 & 0.59 & 0.01 & 0.02 & 0.17 \\
\hline $435-1-1$ & 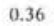 & 6.48 & 4.83 & 0 . & 1 & 13 & 0 & 0.01 & 0. & 0.17 \\
\hline-10 & 0.23 & 5.91 & 2.75 & 0.05 & 25.3 & 11.8 & 0.47 & 0.01 & 0 & 0.20 \\
\hline & 0.23 & & 2.74 & 0.1 & 26 & 11 & 0.45 & 0.02 & & 0.43 \\
\hline & 0.28 & 4.95 & 3.03 & 0.05 & 17.9 & 10.9 & 0.61 & 0.01 & 0. & 0.17 \\
\hline-67 & 0.31 & 4.84 & 3.03 & 0.05 & is. & 9.9 & 0.63 & 01 & ( & 0.15 \\
\hline & 0.25 & 5.28 & 28 & 0. & 21 & 10 & 0.50 & 0.01 & 0. & 0.16 \\
\hline & 0.19 & 2.54 & 1.84 & 0.03 & 13.7 & 8.9 & 0.72 & 0.01 & 0.02 & 0.17 \\
\hline $35 \mathrm{~A}-2$ & 0.17 & 3.16 & 1.80 & 0.03 & 18.2 & 10.4 & 0.57 & 0.01 & 0. & 0.18 \\
\hline $\mathrm{b}$ & 0.23 & 6.79 & 2.01 & 0.06 & 29. & 8.8 & 0.30 & 0.01 & 0. & 0.27 \\
\hline $4-3$ & 0.22 & 4.35 & 2,13 & 0.04 & 20. & 9.9 & 0.49 & 0.01 & 0.02 & 0.18 \\
\hline 5.5 & 0.20 & 4.09 & 2.36 & 0.1 & 20. & 11 & 0.58 & & & \\
\hline $6=2$ & 0.22 & 4.98 & 2.17 & 0.0 & 23.0 & 10. & 0.44 & 0.01 & 0.01 & 0.14 \\
\hline $9-2,1$ & 0.19 & 3.87 & 2.18 & 0.03 & 20.1 & 11.4 & 0.56 & 0.01 & 0.01 & 0.16 \\
\hline $436-1-3$ & & & & & & & & & & \\
\hline & & & & & & & 0 & 1 & & 14 \\
\hline & & & & & & & & 1 & & 15 \\
\hline 7 & 0.23 & 6.14 & 2 & 0. & 26. & 10. & 0.39 & 0.01 & 1 & 0.31 \\
\hline-125 & & & & & 21. & 13 & 0.60 & .01 & & 0.18 \\
\hline & & & & & & & & 1 & & 0.20 \\
\hline & & 6 & & & 2.2 & 18 & 0. & 1 & ( & 0.24 \\
\hline & & & & & & & & & & \\
\hline & & & & & 23 & & 0.42 & i & 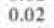 & 0.19 \\
\hline & & & & & 2 & & 0.50 & 1 & & 018 \\
\hline & & & & & & 12 & & & & \\
\hline & & & & & & 14 & & & & 0.18 \\
\hline & & & & & & & & & & 17 \\
\hline & & & & & & 11 & 0. & & & 16 \\
\hline & 0 & 6. & 2.6 & 0 & 24 & 9 & 0.41 & 1 & 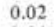 & 0.20 \\
\hline & & & & & & 15 & 0.57 & 12 & & \\
\hline & & & & &  & 12 & & & & 49 \\
\hline & & & & & & & & & & \\
\hline & & & & & & & & 2 & & 52 \\
\hline & & & & & & & & & & 90 \\
\hline & & & & & & & & & & \\
\hline & & & & & & & & & & 87 \\
\hline & & & & & & & & & & \\
\hline & & & & & & & & & & \\
\hline & & & & & & & & 0,10 & 0 & 00 \\
\hline & & & & & & & & & & \\
\hline & & & & & & 12 & & & & 4.46 \\
\hline & & 7. & 5. & & 12 & 9 & 0.75 & 0.33 & 0.44 & 4.22 \\
\hline & & 5 . & & 0. & 17 & 25 & 1. & 0.01 & 0. & 0.20 \\
\hline $42-1,15-2$ & 0.05 & 1.11 & 1.29 & 0.34 & 20.6 & 23.9 & 1.16 & 0.31 & 0.26 & 6,30 \\
\hline
\end{tabular}

distinct changes in $\mathrm{Fe}$ and $\mathrm{Mn}$ concentrations as compared with the hemipelagic section. The variability of $\mathrm{Fe}$ content and the $\mathrm{Fe} / \mathrm{Al}$ ratio, however, increases, and the glauconitic layers are enriched in $\mathrm{Fe}$ up to 5.1 per cent ( $\mathrm{Fe} / \mathrm{Al}$ ratio 0.8). A slight but regular decrease in $\mathrm{Fe} / \mathrm{Ti}$ and $\mathrm{Fe} / \mathrm{Al}$ ratios in siltstone and sandstone layers (Figure 2) is caused by increased $\mathrm{Al}$ and $\mathrm{Ti}$ contents in coarse-grained clastic material as compared with clay matrix. Very small values of the $\mathrm{Mn} / \mathrm{Al}$ ratio (0.0040.006 ) indicate both low $\mathrm{Mn}$ content and increased $\mathrm{Al}$ content in the clastic material.

The Cretaceous shales from Site 439, Cores 439-38 and 439-39, are somewhat enriched in $\mathrm{Fe}$ (4.6 and $4.9 \%$ ), but a higher $\mathrm{Al}$ content $(8.5$ and $9.0 \%$ ) results in a low $\mathrm{Fe} / \mathrm{Al}$ ratio. $\mathrm{Mn}$ is very low $(0.04 \%)$.

The transition from hemipelagic to pelagic sediments through unit II at Site 436 is marked by a gradual increase in Mn from 0.14 per cent at the upper boundary
TABLE 4 - Continued

\begin{tabular}{|c|c|c|c|c|c|c|c|c|c|c|}
\hline $\begin{array}{c}\text { Sample } \\
\text { (interval in } \mathrm{cm} \text { ) }\end{array}$ & $\mathrm{Ti}$ & Al & $\mathrm{Fe}$ & $\mathrm{Mn}$ & $\frac{\mathrm{Al}}{\mathrm{Ti}}$ & $\frac{\mathrm{Fe}}{\mathrm{T}_{1}}$ & $\frac{\mathrm{Fe}}{\mathrm{Al}}$ & $\frac{M n}{A !}$ & $\frac{\mathrm{Mn}}{\mathrm{Fe}}$ & $\frac{M n}{T_{i}}$ \\
\hline 2,10 & 0.32 & 6.24 & 3.57 & 0.05 & 19.3 & 11.0 & 0.57 & 0.01 & 0.01 & \\
\hline $438 \mathrm{~A}-12-2,33-37$ & & 5.39 & 3.23 & 0.05 & 18.0 & 10.8 & & & & 0.19 \\
\hline $\begin{array}{r}8 A-12-2,33-37 \\
18-2,65-69\end{array}$ & $\begin{array}{l}0.20 \\
0.23\end{array}$ & $\begin{array}{l}3.68 \\
4.23\end{array}$ & $\begin{array}{l}2.03 \\
2.24\end{array}$ & $\begin{array}{l}0.03 \\
0.03\end{array}$ & $\begin{array}{l}\begin{array}{l}18.0 \\
18.6\end{array} \\
18 .\end{array}$ & $\begin{array}{r}10.0 \\
9.8\end{array}$ & $\begin{array}{l}0.55 \\
0.53\end{array}$ & $\begin{array}{l}0.01 \\
0.01\end{array}$ & $\begin{array}{l}0.02 \\
0.01\end{array}$ & \\
\hline $26-2,39-43$ & 0.21 & 3.74 & 2.31 & 0.03 & 17.8 & 11.0 & 0.62 & $\begin{array}{l}0.01 \\
0.01\end{array}$ & 0.01 & $\begin{array}{l}0.14 \\
0.15\end{array}$ \\
\hline $36-2,50-54$ & 0.20 & 3.74 & 2.03 & 0.03 & 18.4 & 9.9 & 0.54 & 0.01 & 0.02 & 0.15 \\
\hline 42-2, & 0.28 & 4.89 & 3.43 & 0. & 17.7 & 12.4 & 0. & 0.01 & 0.01 & 0.17 \\
\hline & 0.26 & 4.34 & & & 16.4 & 10.4 & & & 0.01 & 0.15 \\
\hline & $\begin{array}{l}0.33 \\
0.28\end{array}$ & 3.15 & 3.27 & & & & & & 0.01 & 0.12 \\
\hline $\begin{array}{l}52-2,22-27 \\
56-2,35-39\end{array}$ & 0.28 & 5.06 & 2.91 & 0.05 & $\begin{array}{l}18.3 \\
16.7\end{array}$ & 10.5 & 0 . & 0.01 & 0.02 & 17 \\
\hline $\begin{array}{l}56-2,35-39 \\
6-2,125-12\end{array}$ & $\begin{array}{l}0.36 \\
0.25\end{array}$ & $\begin{array}{l}6.02 \\
4.63\end{array}$ & $\begin{array}{l}3.65 \\
2.89\end{array}$ & $\begin{array}{l}0.05 \\
0.05\end{array}$ & $\begin{array}{l}16.7 \\
18.8\end{array}$ & 10.1 & $\begin{array}{l}0.61 \\
0.64\end{array}$ & 0.01 & $\begin{array}{l}0.01 \\
0.02\end{array}$ & 13 \\
\hline $\begin{array}{l}64-2,125-1 \\
70-2,90-94\end{array}$ & $\begin{array}{l}0.25 \\
0.32\end{array}$ & $\begin{array}{l}4.63 \\
5.87\end{array}$ & $\begin{array}{l}2.89 \\
3.65\end{array}$ & $\begin{array}{l}0.05 \\
0.04\end{array}$ &  & $\begin{array}{l}12.0 \\
11.5\end{array}$ & $\begin{array}{l}0.64 \\
0.62\end{array}$ & $\begin{array}{l}0.01 \\
0.01\end{array}$ & $\begin{array}{l}0.02 \\
0.01\end{array}$ & 0.19 \\
\hline $80-2,124-126$ & 0.25 & 4.77 & 2.70 & 0.04 & 19.4 & 11.0 & 0.57 & 0.01 & 0.01 & 0.16 \\
\hline $82-2,100-102$ & 0.35 & 6.13 & 4.04 & 0.05 & 17.3 & 11.4 & 0.66 & 0.01 & 0.01 & 0.15 \\
\hline $8 \mathrm{~B}-12-2,44-45$ & 0.29 & 4.52 & 3.06 & 0.04 & 15.7 & 10.6 & 0.68 & 0.01 & 0.01 & 0.14 \\
\hline $18-2,8$ & 0.38 & 7,13 & 4.17 & & 18.6 & 10.8 & 0.58 & 0.01 & 0.01 & \\
\hline $20-2,75-78$ & 0.32 & 6.64 & 5.13 & 0.03 & 20.9 & 16.1 & 0.77 & 0.01 & 0.01 & 0.10 \\
\hline $439-10-2$ & 0.32 & $\begin{array}{l}5.99 \\
7.8\end{array}$ & 3.84 & 0.03 & 18.5 & 11.8 & 0.64 & 0.01 & 0.01 & \\
\hline $\begin{array}{l}12-1,14 \\
12-2,74\end{array}$ & 0.36 & 7.26 & $\begin{array}{l}2.75 \\
3.34\end{array}$ & $\begin{array}{l}0.03 \\
0.04\end{array}$ & $\begin{array}{l}21.2 \\
20.2\end{array}$ & $\begin{array}{l}7.5 \\
9.3\end{array}$ & $\begin{array}{l}0.35 \\
0.46\end{array}$ & $\begin{array}{l}0.01 \\
0.01\end{array}$ & $\begin{array}{l}0.01 \\
0.01\end{array}$ & \\
\hline & 0.32 & 7.90 & 3.08 & & 24.4 & 9.5 & 0.39 & 0.01 & 0.01 & (1) \\
\hline & 0.29 & 8.19 & 2.70 & 0.03 & 28.4 & 9.4 & 0.33 & 0.01 & 0.01 & 0.11 \\
\hline 38. & 0.41 & 8.52 & 4.63 & 0.04 & 20.6 & 11.2 & 0.54 & 0.01 & 0.01 & \\
\hline $39-1.50-52$ & 0.44 & 8.99 & 4.86 & 0.05 & 20.2 & 10.9 & 0.54 & 0.01 & 0.01 & \\
\hline & & & & & & & & & & \\
\hline & & & & & & & & & 0.01 & 0.15 \\
\hline & $0.2-2$ & 4.9 & 2.88 & 0.04 & 18. & 10 & & & 0.01 & 0.14 \\
\hline 3-6. & & 6.6 & 4.01 & & 17. & 10. & & & 0.01 & 0.14 \\
\hline & & & & & & & & $\begin{array}{l}0.01 \\
0.01\end{array}$ & $\begin{array}{l}0.01 \\
0.02\end{array}$ & 0.13 \\
\hline & & $\begin{array}{r}5.82 \\
4.76\end{array}$ & 3.08 & 0. & $\begin{array}{l}21.1 \\
18.0\end{array}$ & $\begin{array}{l}11.2 \\
10.6\end{array}$ & 0.53 & & 0.02 & 0.17 \\
\hline 3 & 0. & 3.80 & & & & & & & & 0.23 \\
\hline & 0. & 3. & & & & & & & & \\
\hline & 0. & 3. & & & & 11 & & & 0.02 & 19 \\
\hline & 0. & 4.5 & 2.34 & 0. & 15 & 11 & 0.52 & 0.01 & 0.01 & 0.13 \\
\hline $66 \cdot 1,32-34$ & 0.21 & 4.14 & 2.35 & 0.03 & 19.7 & 11.2 & 0.57 & 0.01 & 0.01 & 0.15 \\
\hline & & & & & & & & & 0.02 & \\
\hline & & & & & & & & & & \\
\hline & & .64 & .58 & 0.10 & 20.5 & 11.0 & 0.54 & 0.02 & 0.03 & 0.31 \\
\hline
\end{tabular}

Carbonate nodule.

"Vitric ash.

of the unit to 0.6 per cent at its lower boundary (Figure $6)$. The downhole increase in $\mathrm{Mn}$ as well as in Fe first appears above the upper boundary of unit II, in subunit $\mathrm{Ib}$, corresponding there with a decrease in biogenic silica. However, the Mn concentration increases more rapidly than "excess" $\mathrm{SiO}_{2}$ decreases. The $\mathrm{Mn} / \mathrm{Al}$ ratio increases markedly (from 0.008 to 0.02 in sub-unit Ib to 0.07 at the base of unit $\mathrm{II}$ ), whereas the $\mathrm{Fe} / \mathrm{Al}$ ratio does not show any regular increase in unit II. This different behavior of the two elements in transitional sediments is reflected by their ratios: the $\mathrm{Mn} / \mathrm{Fe}$ ratio in typical hemipelagic sediments (Core 436-29) equals 0.02; downhole it increases to 0.04 (Core 436-31), and further through unit II to 0.1 (Core 436-38).

The pelagic clay of unit III at Site 436 is enriched both in $\mathrm{Fe}$ and $\mathrm{Mn}$, but the relative concentration of manganese is much greater. Fe content ranges from 5.0 to 8.5 per cent, the $\mathrm{Fe} / \mathrm{Al}$ ratio from 0.57 to 1.45 , and the $\mathrm{Fe}$ / Ti ratio from 9.7 to 25.0. Maximum values were detected in a sample of zeolitic (?) clay from Core 436-41, just above chert. This clay differs from the typical dark-brown pelagic clay in its lighter color, low $\mathrm{Al}_{2} \mathrm{O}_{3}$ content, high $\mathrm{SiO}_{2} / \mathrm{Al}_{2} \mathrm{O}_{3}$ ratio (4.4), and low $\mathrm{Mn}$ content $(0.06 \%)$. In the pelagic clay, Fe does not exceed 5.7 per cent, whereas $\mathrm{Mn}$ content ranges from 0.7 to 3.4 per cent, the $\mathrm{Mn} / \mathrm{Al}$ ratio ranges from 0.09 to 0.39 , the $\mathrm{Mn} / \mathrm{Ti}$ ratio ranges from 1.7 to 8.5 , and the $\mathrm{Mn} / \mathrm{Fe}$ ratio ranges from 0.14 to 0.64 . These figures show that the pelagic clay belongs to a high-manganese, low-iron variety. 
GEOCHEMISTRY OF THE JAPAN TRENCH SEDIMENTS



Figure 7. Relation between Fe and $\mathrm{Ti}$ in the Japan Trench sediments. The 10.6 line approximates the $\mathrm{Fe} / \mathrm{Ti}$ ratio for the hemipelagic sediments, whereas the points far below this line show "excess" iron with respect to titanium, likely that of authigenic pyrite or iron oxides.

A brown-chert sample from Core $436-42$ is also strongly enriched in $\mathrm{Mn}$ relative to $\mathrm{Fe}(0.34), \mathrm{Al}(0.3)$, and $\mathrm{Ti}(6.3)$.

\section{MAGNESIUM, CALCIUM, AND POTASSIUM}

We could not infer any distinct regularities from the $\mathrm{Mg}$ and $\mathrm{Ca}$ variation patterns in the Japan Trench sediments (Tables 1 and 2), except for several cases of diagenetic calcite precipitation, which results in a sharp increase in $\mathrm{Ca}$ content. Both $\mathrm{Ca}$ and $\mathrm{Mg}$ are characterized by narrow ranges in most samples, between 0.9 and 2 per cent for $\mathrm{CaO}$, and between 1 and 3 per cent for $\mathrm{MgO}$, with rather irregular variations.

$\mathrm{K}_{2} \mathrm{O}$ concentrations range from 1 to 2.1 per cent in most hemipelagic sediments on the landward trench slope (Sites 438, 435, 440, 441, 434), but tend to increase on the oceanic slope (Site 436), where the hemipelagic section contains 1.8 to 2.7 per cent $\mathrm{K}_{2} \mathrm{O}$, the transitional unit II contains 2.2 to 3.3 per cent $\mathrm{K}_{2} \mathrm{O}$, and the pelagicclay unit contains 2.3 to 4.1 per cent $\mathrm{K}_{2} \mathrm{O}$. Siltstones and sandstones are also somewhat enriched in $\mathrm{K}_{2} \mathrm{O}$ (up to $2.5 \%$ ) at Sites 438 and 439.

\section{BULK COMPOSITION OF SIZE FRACTIONS}

We analyzed two dominant size fractions - less than $1 \mu \mathrm{m}$ (clay), and 1 to $10 \mu \mathrm{m}$ (fine silt) - in three samples from Site 436, one of diatomaceous radiolarian clay (unit II; Core 436-36) and two of pelagic clay (sub-unit IIIa; Cores 436-39 and 436-40), using routine wetchemical bulk silicate analysis (Table 5). The data show that $\mathrm{SiO}_{2}, \mathrm{CaO}, \mathrm{Na}_{2} \mathrm{O}$, and, to a lesser extent, $\mathrm{TiO}_{2}$ and $\mathrm{K}_{2} \mathrm{O}$ tend to be concentrated in the coarser fraction; $\mathrm{Fe}_{2} \mathrm{O}_{3}$ and $\mathrm{MgO}$ apparently are associated with clay, whereas strong concentration of $\mathrm{Mn}$ in the clay fraction appears in only one sample of the pelagic clay. $\mathrm{Al}_{2} \mathrm{O}_{3}$ is evenly distributed between the two fractions in all samples. Water content (loss on ignition) is much higher in the clay fraction, in good accordance with concentration of clay minerals and Fe-hydroxides in the finegrained material. If calculated on a water-free basis, the
TABLE 5

Bulk Wet-Chemical Analyses (wt. \%) of Certain Size Fractions Separated from Site 436 Sediments

\begin{tabular}{lrrrrrr}
\hline \multirow{2}{*}{ Component } & \multicolumn{2}{c}{$436-36-3,50-54 \mathrm{~cm}$} & \multicolumn{2}{c}{$436-39-5,76-80 \mathrm{~cm}$} & \multicolumn{2}{c}{$436-40-4,54-58 \mathrm{~cm}$} \\
& $<1 \mu \mathrm{m}$ & $1-10 \mu \mathrm{m}$ & $<1 \mu \mathrm{m}$ & $1-10 \mu \mathrm{m}$ & $<1 \mu \mathrm{m}$ & $1-10 \mu \mathrm{m}$ \\
\hline $\mathrm{SiO}_{2}$ & 49.34 & 60.54 & 43.30 & 59.47 & 44.86 & 58.06 \\
$\mathrm{TiO}_{2}$ & 0.58 & 0.70 & 0.61 & 0.90 & 0.58 & 0.89 \\
$\mathrm{Al}_{2} \mathrm{O}_{3}$ & 16.92 & 15.26 & 16.38 & 17.70 & 17.54 & 15.66 \\
$\mathrm{Fe}_{2} \mathrm{O}_{3}$ & 7.54 & 4.67 & 7.19 & 4.83 & 6.81 & 3.28 \\
$\mathrm{FeO}$ & 1.75 & 1.75 & 1.34 & 0.82 & 1.23 & 2.88 \\
$\mathrm{MnO}$ & 0.22 & 0.28 & 5.08 & 0.81 & 3.88 & 3.48 \\
$\mathrm{MgO}$ & 2.01 & 1.05 & 2.14 & 0.52 & 2.62 & 1.67 \\
$\mathrm{CaO}$ & 0.13 & 0.68 & 0.39 & 1.30 & 0.28 & 0.43 \\
$\mathrm{~K} 2 \mathrm{O}$ & 3.09 & 3.42 & 2.25 & 3.56 & 3.40 & 4.65 \\
$\mathrm{Na} 2 \mathrm{O}$ & 0.16 & 0.84 & 0.47 & 0.79 & 0.63 & 0.72 \\
$\mathrm{~L} .0 .1$. & 17.84 & 10.80 & 20.19 & 9.22 & 18.12 & 8.19 \\
Total & 99.90 & 100.00 & 99.90 & 99.83 & 99.90 & 99.90 \\
\hline
\end{tabular}

distributions of elements between the two fractions do not change fundamentally; however, $\mathrm{Al}_{2} \mathrm{O}_{3}$ content appears to be somewhat greater in the clay fraction.

Composition of the fraction less than $1 \mu \mathrm{m}$ in radiolarian clay differs from that in pelagic brown clay by its higher $\mathrm{SiO}_{2}$ content and $\mathrm{SiO}_{2} / \mathrm{Al}_{2} \mathrm{O}_{3}$ ratio $(2.9$ and 2.6-2.7, respectively), and by lower $\mathrm{MnO}, \mathrm{CaO}$, and $\mathrm{Na}_{2} \mathrm{O}$; however, there are no regular changes in $\mathrm{MgO}$, $\mathrm{Al}_{2} \mathrm{O}_{3}, \mathrm{~K}_{2} \mathrm{O}$, or $\mathrm{Fe}_{2} \mathrm{O}_{3}$.

\section{TRACE ELEMENTS}

We applied two methods to determine trace-element concentrations in sediments: (1) quantitative spectrography, using the SGD-I-A and SG-I-A standards for $\mathrm{Sn}, \mathrm{Pb}, \mathrm{Zn}, \mathrm{Cu}, \mathrm{Cr}, \mathrm{V}, \mathrm{B}$, and $\mathrm{Ag}$; and (2) atomic absorption for $\mathrm{Cr}, \mathrm{Zn}, \mathrm{Cu}, \mathrm{Ni}$, and $\mathrm{Co}$. We carried out the spectral analyses on bulk samples and size fractions less than $1 \mu \mathrm{m}, 1$ to $10 \mu \mathrm{m}$, and more than $10 \mu \mathrm{m}$. For spectral analyses, we used the samples from Leg 56 holes which have been prepared for X-ray diffractometry, so that clay minerals were determined in the same set. For atomic absorption, we used another set of samples from both Leg 56 and Leg 57 holes, taken for major-element geochemistry. Therefore, results of the two methods cannot be compared directly. However, the results obtained by the two methods in nearby or alternating intervals are in most cases in a good accord.

The Neogene to Quaternary hemipelagic sediments drilled during both legs show rather monotonous distributions of trace elements, except for rare deviations which we shall discuss (Tables 6 and 7; Figures 2-6).

Copper content in the hemipelagic sediments of the upper trench slope (Sites 438, 435) is evenly low and ranges from 22 to $50 \mathrm{ppm}$ (Figures 2 and 3). It increases somewhat downslope, being 44 to $63 \mathrm{ppm}$ at Site 440 (Figure 4), and 73 to $83 \mathrm{ppm}$ at Site 441 . The deepest section, at Site 434 (Figure 5), shows some sharp, irregular variations in $\mathrm{Cu}$ concentration: maximum values increase to $116 \mathrm{ppm}$, and minimum values decrease to as little as $14 \mathrm{ppm}$. Partially, these variations seem to correspond with biogenic-silica content, but the correlation is too weak to infer any certain conclusions. We found further increase in $\mathrm{Cu}$ on the oceanic trench slope at Site 436 (Figure 6), where in a single sample $200 \mathrm{ppm}$ 
TABLE 6

Trace Elements in the Japan Trench Sediments, as Determined by Atomic-Absorption Analysis (ppm)

\begin{tabular}{|c|c|c|c|c|c|}
\hline $\begin{array}{c}\text { Sample } \\
\text { (interval in } \mathrm{cm} \text { ) }\end{array}$ & $\mathrm{Cu}$ & $\mathrm{Zn}$ & $\mathrm{Ni}$ & Co & $\mathrm{Cr}$ \\
\hline $434-1-2,64-69$ & 65 & 82 & 42 & 28 & 26 \\
\hline $5-1,13$ & 110 & 260 & 47 & 43 & 96 \\
\hline $20-1,54-58$ & 116 & 105 & 34 & 14 & 39 \\
\hline $28-1,100-102$ & 64 & 118 & 46 & 25 & 36 \\
\hline $31-1,47-51$ & 82 & 90 & 50 & 25 & 44 \\
\hline $434 \mathrm{~B}-11-1,100-102$ & 44 & 77 & 35 & 12 & 25 \\
\hline $13, \mathrm{CC}^{\mathrm{b}}$ & 4 & 42 & 24 & 4 & 10 \\
\hline $435-6-4,90-94$ & 39 & 93 & 29 & 26 & 28 \\
\hline $11-1,64-67$ & 44 & 91 & 25 & 13 & 29 \\
\hline $15-3,31-35$ & 40 & 85 & 32 & 22 & 30 \\
\hline $435 \mathrm{~A}-2-1,38-42$ & 42 & 71 & 40 & 17 & 28 \\
\hline $9-2,100$ & 36 & 87 & 30 & 15 & 28 \\
\hline $436-4-4,88-92$ & 70 & 110 & 48 & 12 & 45 \\
\hline $19-1,94-98$ & 200 & 80 & 25 & 17 & 32 \\
\hline $21-1,5$ & 106 & 104 & 4. & 22 & 40 \\
\hline $29-1,50$ & 86 & 86 & 3 & 22 & 21 \\
\hline $34-1,60$ & 74 & 88 & 52 & 24 & 42 \\
\hline $34-1,85-$ & 66 & 90 & 30 & 13 & 37 \\
\hline $38-1,96-100$ & 200 & 130 & 80 & 35 & 28 \\
\hline $39-1,1$ & 08 & 142 & 275 & 120 & 30 \\
\hline $40-6,4$ & 228 & 172 & 420 & 170 & 30 \\
\hline $42-1,1$ & 73 & 42 & 3 & 65 & 5 \\
\hline $438-3-2,100-1$ & 2 & 86 & 31 & 16 & 68 \\
\hline $10-2,112$ & 28 & 85 & 43 & 20 & 47 \\
\hline $438 \mathrm{~A}-12-2,33-37$ & 29 & 74 & 22 & 9 & 38 \\
\hline $26-2,39-43$ & 0 & 83 & 34 & 30 & 28 \\
\hline $36-$ & 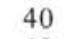 & 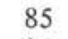 & 3 & 7 & 27 \\
\hline $42-2,9$ & 0 & 95 & 42 & 28 & 42 \\
\hline $49-2,6$ & 34 & 105 & 5 & 18 & 45 \\
\hline $52-2,22-27$ & 36 & 86 & 25 & 10 & 46 \\
\hline $64-2,125-127$ & 44 & 105 & 40 & 18 & 30 \\
\hline 7 & 50 & 12 & 4 & 12 & 43 \\
\hline $80-2,1$ & 46 & 115 & & 0 & 27 \\
\hline $82-2,1$ & 38 & 91 & 28 & 14 & 30 \\
\hline $438 \mathrm{~B}-12-2,44-45$ & 31 & 90 & 42 & 14 & 45 \\
\hline $18-2,88-93$ & 26 & 92 & 56 & 20 & 92 \\
\hline $20-2,75-78$ & 15 & & 3 & 18 & 92 \\
\hline $39-12-1,146-$ & 8 & 5 & & 8 & 36 \\
\hline $18-2,74-$ & 13 & 74 & 26 & 12 & 48 \\
\hline $26-1,73-75$ & 15 & 80 & 30 & 23 & 26 \\
\hline $28-1,87-90$ & 10 & 52 & 18 & 18 & 22 \\
\hline $38-1,3$ & & & & 17 & 38 \\
\hline 39-1, & & 8 & 3 & 2 & 44 \\
\hline $440-4-1,28-32$ & 3 & 91 & 50 & 32 & 52 \\
\hline$-1,124-128$ & 44 & 72 & 26 & 9 & 38 \\
\hline 440B-12-1, 73-77 & 63 & 88 & 56 & 22 & 45 \\
\hline $16-1,127-131$ & 56 & 90 & 60 & 28 & 28 \\
\hline $32-1,42-45$ & 60 & 78 & 22 & 12 & 16 \\
\hline $50-1,11$ & 62 & 93 & 56 & 22 & 18 \\
\hline $66-1,32-$ & 60 & 104 & 54 & 20 & 21 \\
\hline $441-8-1,104-108$ & 73 & 105 & 45 & 20 & 44 \\
\hline $441 \mathrm{~B}-2-1,91-93$ & 83 & 100 & 50 & 20 & 46 \\
\hline
\end{tabular}

${ }_{b}^{a}$ Contaminated by rust from drilling pipe.

${ }^{\mathrm{b}}$ Calcareous concretion.

${ }^{\mathrm{c}}$ Chert.

of $\mathrm{Cu}$ was detected, whereas in several other samples $\mathrm{Cu}$ content is about $100 \mathrm{ppm}$.

The distribution of copper among different size fractions (Table 7) is indicative of its apparent association with clay, although in several cases the copper content is higher in medium $(1-10 \mu \mathrm{m})$ or coarse $(>10 \mu \mathrm{m})$ fractions.
Average $\mathrm{Cu}$ content in the Japan Trench hemipelagic sediments, calculated from 40 atomic-absorption analyses, is $62.1 \mathrm{ppm}$ (Table 8), thus it is lower than the averrage for Holocene hemipelagic diatomaceous clay from the North Pacific (129 ppm) calculated by Skornyakova (1976), but almost equal to the average for lithologically similar Neogene sediments of the Bering Sea from DSDP Site 191 (61 ppm).

Zinc content in the Japan trench hemipelagic sediments is higher than that of copper and is almost uniform at the various sites along the transect. It ranges from 70 to $145 \mathrm{ppm}$, as determined by atomic absorption. The average concentration, $92.3 \mathrm{ppm}$ (Table 8), is almost equal to that obtained by Skornyakova (1976) for North Pacific hemipelagic diatomaceous clay (97 $\mathrm{ppm}$ ) and to our figure of $93 \mathrm{ppm}$ for Site 191 sediments from the Bering Sea. Spectral analyses show several lower values of $\mathrm{Zn}$ content.

$\mathrm{Zn}$ is apparently concentrated in the finest grain-size fraction, where we detected up to $460 \mathrm{ppm}$. It is lowest in the medium fraction, which is most enriched in biogenic silica, whereas the coarse fraction in some cases contains somewhat more zinc, possibly associated with pyrite crystals. There is a weak positive correlation of zinc with such indicators of particulate matter as $\mathrm{Al}$, $\mathrm{Ti}$, and $\mathrm{Fe}$, and a negative correlation with "excess" $\mathrm{SiO}_{2}$.

Nickel content in the hemipelagic sediments is lower than the zinc content, and about equal to or lower than the copper content. The atomic-absorption figures (Table 6) vary from 18 to $74 \mathrm{ppm}$, averaging $39.7 \mathrm{ppm}$ (Table 8), which is close to the average concentration of nickel in Site 191 sediments (38 ppm), and to that for Holocene hemipelagic diatomaceous clay of the western North Pacific (44 ppm) according to Skornyakova (1976). However, it is less than the $\mathrm{Ni}$ content in "average" sedimentary rocks ( $95 \mathrm{ppm})$ calculated by Vinogradov (1962), and less than the average for North Pacific sediments $(120 \mathrm{ppm})$ according to Boström (1976). Spectral-analysis data (Table 7) in the majority of cases show satisfying agreement with the atomicabsorption data, although they tend to be somewhat lower: values of 10 to $20 \mathrm{ppm}$ were determined for Sites 434 and 435 , whereas on the graph for Site 436 (Figure 6) spectral analyses plot to the left of the atomic absorption data. We could not infer any distinct lateral or vertical trends in Ni content (Figures 2-6).

The distribution of $\mathrm{Ni}$ among different size fractions does not show any distinct regularities, but commonly $\mathrm{Ni}$ content is lowest in the medium fraction (1 to $10 \mu \mathrm{m})$, likely because of its higher biogenic-silica content.

Cobalt content is low throughout the hemipelagic section. It does not exceed $30 \mathrm{ppm}$, decreasing in some samples to 9 or $10 \mathrm{ppm}$, according to the atomicabsorption data (Table 6), and even less (3-7 ppm) according to spectral analyses (Table 7). The average for 40 atomic-absorption analyses is $20.2 \mathrm{ppm}$, equal to the average for sedimentary rocks (Vinogradov, 1962), or to the average Holocene Recent North Pacific diatomaceous clay (25 ppm; Skornyakova, 1976), but twice the average obtained for Site 191 sediments $(10 \mathrm{ppm})$. 
Boström's (1976) average for North Pacific sediments is somewhat greater $(32 \mathrm{ppm})$.

The cobalt distribution patterns are similar at all sites on the Japan transect, and downhole variations are rather insignificant. Co is almost evenly distributed among the size fractions, but its content tends to decrease in the fraction 1 to $10 \mu \mathrm{m}$ at Sites 434 and 435 , whereas at Site 436 we found a slight increase with decreasing grain size (Table 7).

Chromium content in the hemipelagic sediments is higher than that of $\mathrm{Co}$ and lower than that of $\mathrm{Cu}$ or $\mathrm{Zn}$, whereas interrelations with $\mathrm{Ni}$ are variable. The concentrations range from 16 to $68 \mathrm{ppm}$, according to atomicabsorption data (Table 6), averaging $34.7 \mathrm{ppm}$ (Table $8)$. This average is lower than that obtained for Bering Sea sediments at Site 191 (52 ppm), and much less than the average for sedimentary rocks $(100 \mathrm{ppm})$. The spectral analyses (Table 7) are in good accordance with the atomic-absorption data, showing variations from 13 to $41 \mathrm{ppm}$.

The chromium concentrations are almost uniform at the various sites, but average values are somewhat higher on the upper trench slope (Site 438, and the Pleistocene section at Site 435), likely because of moreabundant clastic material. We found a rather strong positive correlation of chromium with titanium (correlation coefficient 0.72 ; Figure 8) and a weaker, but important correlation with aluminum (correlation coefficient 0.53; Figure 9) and with iron (correlation coefficient 0.55 ; Figure 10). A negative correlation (coefficient 0.53 ) exists between $\mathrm{Cr}$ and "excess" $\mathrm{SiO}_{2}$.

The distribution of $\mathrm{Cr}$ among the size fractions is unexpectedly irregular: it does not show a distinct increase in the coarse fraction, except for Site 435 (Table 7). At Site $436, \mathrm{Cr}$ is most abundant in the finest clay fraction.

Other trace elements, $\mathrm{Sn}, \mathrm{Pb}, \mathrm{V}, \mathrm{B}$, and $\mathrm{Ag}$, were determined by spectral analyses only for the Leg 56 holes (Table 7).

Tin content is low throughout the hemipelagic section (1-6 ppm). There is a decrease at Site 435 (1-2 ppm), as compared with Site 434 sediments (2-6 ppm). Tin tends to concentrate in the clay fraction, but the trend is hardly recognizable.

Lead content ranges from 10 to as high as $3000 \mathrm{ppm}$; however, the latter value, found in one sample from Site 435 , seems to be caused by an artificial contamination (extremely high $\mathrm{Zn}$ content was detected in the same sample). High $\mathrm{Pb}$ content (91-480 ppm), was also detected in three samples from Site 434. In other cases, it does not exceed $60 \mathrm{ppm}$, being commonly below 40 $\mathrm{ppm}$. The average, calculated for 35 spectral analyses (extreme values excluded), is $23 \mathrm{ppm}$, close to the average for sedimentary rocks (Vinogradov, 1962; 20 ppm) and for Holocene diatomaceous clay of the North Pacific (Skornyakova, 1976; $21 \mathrm{ppm}$ ), and somewhat higher than the average for Site 191 sediments (14 ppm). The distribution of lead among the different size fractions is rather irregular.

Vanadium in the hemipelagic sediments shows wide variations, ranging from 45 to $160 \mathrm{ppm}$, the high and low values often occurring close to each other (Table 7; Figures 3-6). The average of 39 spectral analyses is 93.8 ppm, almost equal to that for the Bering Sea sediments drilled at Site 191 (93 ppm) and to Boström's (1976) average for North Pacific sediments (93 ppm), but below the Skornyakova's (1976) figures (116 and 121 ppm) for North Pacific hemipelagic sediments.

Relatively low vanadium content $(45-79 \mathrm{ppm})$ was found in the highly siliceous Pliocene sediments at Site 435 , whereas higher concentrations more than $100 \mathrm{ppm}$ occur more frequently in the Quaternary at this site, as well as in the upper part of the section at Site 436 (subunit Ia). At Site 434, the higher values occur sporadically throughout. Vanadium is apparently concentrated in the clay fraction $(<1 \mu \mathrm{m})$, where it increases up to 260 ppm (Table 7).

Boron content in the Neogene to Quaternary hemipelagic sediments is rather low, ranging from 40 to 110 ppm. The average of 39 analyses (Table 7) is $77.2 \mathrm{ppm}$, considerably lower than averages for Bering Sea sediments at Site 191 (112 ppm), for sedimentary rocks according to Vinogradov $(1962 ; 100 \mathrm{ppm})$ or for North Pacific pelagic sediments according to $\mathrm{K}$. Boström $(1976,130 \mathrm{ppm})$. The concentration of boron is commonly highest in the clay fraction, but absolute values are moderate, never exceeding $150 \mathrm{ppm}$. Differences among the sites seem to be insignificant.

Silver content in oceanic sediments is poorly known, and average values for large regions are lacking, as far as we know. The average concentration in Bering Sea sediments at Site 191 appeared to be $0.19 \mathrm{ppm}$. Our spectral analyses (Table 7) show a range from 0.02 to as high as $1.9 \mathrm{ppm}$. We distinguished two intervals considerably enriched in silver: one at Site 434 (354-601 m; Figure 5), and another at Site 436 (271-303 m; Figure 6). The first interval, associated with unit II (tuffite and vitric diatomaceous mud), is more prominent; silver content in it ranges from 0.63 to $1.9 \mathrm{ppm}$ (average of seven analyses $1.1 \mathrm{ppm})$. The second interval contains 0.21 to $0.55 \mathrm{ppm}$ silver and belongs to sub-unit $\mathrm{Ib}$ (vitric diatomaceous mudstone). Both intervals are early Pliocene to late Miocene. The rest of the hemipelagic section at these sites is characterized by rather low silver content (commonly less than $0.1 \mathrm{ppm}$ ). The high silver content is apparently associated with the clay fraction, which contains up to $6.3 \mathrm{ppm}$ silver, but other fractions in these intervals are also somewhat enriched in silver as compared with layers above. Silver content in the Site 435 sediments is higher than that in non-enriched upper layers at other sites. In the lower portion of the section, it increases to $0.48 \mathrm{ppm}$.

The Miocene turbidites and Oligocene sandstones at Sites 438 and 439 differ from the aforementioned hemipelagic sediments by their lower and more variable copper, zinc, and cobalt contents, as well as by some increase in chromium (Table 6). Copper concentration ranges from 8 to $26 \mathrm{ppm}$ (average of six samples 14.5 $\mathrm{ppm})$; zinc concentration in the same samples ranges from 52 to $92 \mathrm{ppm}$ (average $69 \mathrm{ppm}$ ); and cobalt ranges from 8 to $23 \mathrm{ppm}$ (average $16.5 \mathrm{ppm}$ ). Chromium ranges from 22 to $92 \mathrm{ppm}$ (average $52.7 \mathrm{ppm}$ ); however, rela- 
TABLE 7

Trace Elements in Leg 56 Sediments (bulk samples and size fractions in $\mu \mathrm{m}$ ), as Determined by Quantitative Spectral Analysis (ppm)

\begin{tabular}{|c|c|c|c|c|c|c|c|c|c|c|c|c|c|c|c|c|c|}
\hline \multirow{2}{*}{$\begin{array}{l}\text { Sampled } \\
\text { Section }\end{array}$} & \multirow{2}{*}{$\begin{array}{l}\text { Sub- } \\
\text { bottom } \\
\text { Depth } \\
\text { (m) }\end{array}$} & \multicolumn{4}{|c|}{ Sn } & \multicolumn{4}{|c|}{$\mathrm{Pb}$} & \multicolumn{4}{|c|}{$\mathrm{Zn}$} & \multicolumn{4}{|c|}{$\mathrm{Cu}$} \\
\hline & & $<1$ & $1-10$ & $>10$ & Bulk & $<1$ & $1-10$ & $>10$ & Bulk & $<1$ & $1-10$ & $>10$ & Bulk & $<1$ & $1-10$ & $>10$ & Bulk \\
\hline $434-1-2$ & 1.5 & 3 & 4 & 2 & 3 & 68 & 14 & 27 & 91 & 460 & 39 & 74 & 79 & 96 & 16 & 60 & 66 \\
\hline $4-1$ & 26.0 & 2 & 2 & 2 & 2 & 35 & 14 & 14 & 57 & 370 & 89 & 51 & 78 & 140 & 45 & 45 & 66 \\
\hline $7-1$ & 55.0 & 3 & 2 & 3 & 4 & 35 & 10 & 12 & 20 & 320 & 51 & 140 & 96 & 115 & 39 & 60 & 66 \\
\hline $9-1$ & 74.0 & 3 & 2 & 2 & 2 & 32 & 20 & 13 & 30 & 320 & 150 & 63 & 89 & 19 & 66 & 45 & 52 \\
\hline $12-1$ & 102.0 & 2 & 4 & 2 & 3 & 10 & 6 & 16 & 25 & 170 & 52 & 370 & 89 & 45 & 24 & 74 & 52 \\
\hline $16-1$ & 140.0 & 5 & 2 & 1 & 3 & 23 & 8 & 7 & 35 & 160 & 52 & 41 & 78 & 96 & 40 & 20 & 74 \\
\hline $23-1$ & 206.0 & 2 & 2 & 1 & 3 & 28 & 8 & 10 & 22 & 210 & 35 & 180 & 89 & 79 & 23 & 50 & 49 \\
\hline $28-1$ & 254.0 & 5 & 2 & 4 & 4 & 85 & 59 & 105 & 150 & 460 & 50 & 130 & 120 & 79 & 22 & 52 & 40 \\
\hline $31-1$ & 282.5 & 2 & 5 & 2 & 3 & 140 & 130 & 380 & 480 & 240 & 55 & 145 & 81 & 66 & 52 & 66 & 60 \\
\hline $31-1$ & 283.0 & 4 & 2 & 3 & 2 & 17 & 13 & 21 & 23 & 250 & 60 & 125 & 72 & 110 & 52 & 120 & 100 \\
\hline $434 \mathrm{~B}-8-2$ & 354.0 & 3 & 2 & 2 & 2 & 14 & $7^{\circ}$ & 10 & 16 & 400 & 44 & 380 & 130 & 100 & 31 & 74 & 66 \\
\hline $16-3$ & 432.0 & 4 & 3 & 4 & 2 & 10 & 8 & 10 & 15 & 130 & 38 & 160 & 110 & 66 & 28 & 74 & 79 \\
\hline $19-2$ & 458.0 & 3 & 3 & 3 & 4 & 13 & 10 & 17 & 20 & 300 & 71 & 110 & 89 & 100 & 52 & 74 & 96 \\
\hline $24-2$ & 507.0 & 4 & 3 & 3 & 4 & 14 & 18 & 21 & 19 & 150 & 68 & 130 & 79 & 110 & 71 & 110 & 71 \\
\hline $28-1$ & 543.0 & 4 & 2 & 2 & 2 & 11 & 8 & 11 & 20 & 130 & 43 & 120 & 51 & 22 & 27 & 96 & 14 \\
\hline $34-2$ & 601.0 & 3 & 2 & 3 & 2 & 21 & 13 & 22 & 25 & 220 & 35 & 95 & 51 & 110 & 52 & 140 & 110 \\
\hline $34-2$ & 601.0 & 3 & 2 & 3 & 3 & 22 & 6 & 18 & 19 & 200 & 38 & 140 & 76 & 87 & 40 & 110 & 66 \\
\hline $34-2$ & 601.5 & 3 & 3 & 4 & 6 & 90 & 39 & 125 & 29 & 160 & 66 & 240 & 79 & 87 & 44 & 57 & 55 \\
\hline $435-1-1$ & 0.5 & 3 & 1 & 1 & 1 & 9 & 6 & 10 & 22 & 250 & 50 & 91 & 63 & 66 & 16 & 13 & 22 \\
\hline $2-4$ & 12.5 & 1 & 2 & 2 & 1 & 12 & 10 & 21 & 25 & 660 & 47 & 95 & 66 & 34 & 12 & 51 & 33 \\
\hline $5-2$ & 38.5 & 3 & 2 & 2 & 2 & 20 & 15 & 15 & 19 & 240 & 95 & 85 & 95 & 130 & 27 & 16 & 50 \\
\hline $8-2$ & 67.0 & 1 & 1 & 2 & 2 & 1900 & 3400 & 3000 & 3000 & 300 & 64 & 270 & 170 & 80 & 27 & 20 & 50 \\
\hline $11-3$ & 97.5 & 2 & 2 & 1 & 1 & 22 & 12 & 19 & 16 & 180 & 28 & 41 & 79 & 80 & 8 & 24 & 38 \\
\hline $13-3$ & 116.0 & 1 & 2 & 2 & 1 & 76 & 48 & 81 & 21 & 140 & 38 & 53 & 46 & 40 & 25 & 53 & 22 \\
\hline $16-1$ & 141.5 & 1 & 2 & 1 & 1 & 20 & 24 & 15 & 48 & 30 & 63 & 36 & 79 & 38 & 30 & 25 & 26 \\
\hline $435 A-4-2$ & 170.5 & 2 & 2 & $i$ & $i$ & 20 & 19 & 18 & 50 & 100 & 40 & 85 & 69 & 25 & 19 & 30 & 25 \\
\hline $7-1$ & 197.5 & 2 & 2 & 2 & 2 & 4 & 6 & 11 & 10 & 180 & 28 & 41 & 220 & 55 & 24 & 42 & 44 \\
\hline $10-1$ & 226.0 & 3 & 2 & 1 & 1 & 37 & 9 & 11 & 32 & 330 & 28 & 49 & 56 & 60 & 16 & 19 & 47 \\
\hline $436-1-3$ & 3.0 & 2 & 1 & 2 & 2 & 32 & 42 & 33 & 21 & 140 & 50 & 42 & 56 & 100 & 32 & 30 & 60 \\
\hline $4-1$ & 27.0 & 2 & i & 2 &  & 14 & 15 & 11 & 20 & 130 & 38 & 33 & 46 & 86 & 27 & 19 & 40 \\
\hline $9-2$ & 76.0 & 2 & 1 & 1 & 2 & 32 & 15 & 17 & 34 & 220 & 40 & 36 & 54 & 165 & 31 & 30 & 91 \\
\hline $15-4$ & 136.5 & 2 & 2 & 2 & 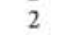 & 34 & 23 & 40 & 21 & 200 & 100 & 63 & 81 & 130 & 60 & 34 & 71 \\
\hline $27-3$ & 249.0 & 1 & 1 & 1 & 2 & 9 & 10 & 12 & 10 & 100 & 95 & 120 & 63 & 52 & 33 & 47 & 47 \\
\hline $29-1$ & 265.0 & 2 & 2 & 4 & 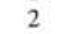 & 12 & 12 & 11 & 10 & 150 & 340 & 160 & 83 & 83 & 140 & 57 & 39 \\
\hline $30-3$ & 271.0 & 2 & 2 & 2 & 2 & 9 & 1. & 7 & 25 & 15 & 180 & 125 & 0 & 81 & 60 & 100 & 100 \\
\hline $31-3$ & 287.0 & 2 & 2 & 2 & 5 & 34 & 38 & 19 & 13 & 175 & 150 & 54 & . & 50 & 40 & 9 & 23 \\
\hline $31-3$ & 287.5 & 1 & 1 & 2 & 4 & 9 & 7 & 11 & 10 & 19 & 130 & 200 & 5 & 40 & 45 & 84 & 23 \\
\hline $32-2$ & 295.0 & 1 & 2 & 2 & 2 & 11 & 12 & 11 & 11 & 150 & 230 & 255 & 48 & 61 & 115 & 135 & 29 \\
\hline $33-1$ & 303.0 & 1 & 2 & 1 & 2 & 5 & 8 & 9 & 13 & 66 & 160 & 69 & 54 & 28 & 58 & 35 & 30 \\
\hline 34. & 315.5 & 2 & 2 & 2 & 2 & 10 & 12 & 14 & 17 & 110 & 91 & 63 & 48 & 40 & 52 & 39 & 39 \\
\hline 3 & 325.0 & 2 & 2 & 2 & 2 & 11 & 14 & 10 & 17 & 115 & 260 & 220 & 63 & 60 & 91 & 120 & 39 \\
\hline $36-3$ & 334.0 & 2 & 2 & 2 & 2 & 19 & 14 & 22 & 14 & 160 & 95 & 130 & 63 & 190 & 79 & 130 & 84 \\
\hline $37-4$ & 345.5 & 2 & 2 & 2 & 3 & 15 & 1 & 12 & 26 & 14 & 95 & 50 & 76 & 125 & 100 & 64 & 130 \\
\hline $38-2$ & 352.0 & 2 & 2 & 1 & 2 & 26 & 21 & 14 & 26 & 180 & 91 & 74 & 100 & 600 & 215 & 115 & 330 \\
\hline $38-$ & 358.0 & 2 & 2 & 1 & 2 & 100 & 26 & 56 & 66 & 190 & 60 & 40 & 65 & 350 & 210 & 52 & 150 \\
\hline $39-2$ & 361.0 & 2 & 2 & 5 & 3 & 3 & 7 & 6 & 9 & 440 & 250 & 140 & 140 & 205 & 245 & 130 & 245 \\
\hline $39-5$ & 366.0 & 2 & 2 & 2 & 2 & 27 & 14 & 42 & 48 & 240 & 81 & 135 & 140 & 310 & 100 & 145 & 270 \\
\hline $40-4$ & 374.0 & 2 & 1 & 2 & 3 & 36 & 29 & 16 & 49 & 210 & 115 & 120 & 110 & 195 & 100 & 100 & 175 \\
\hline $41-1$ & 378. & 2 & 0 & 0 & 2 & 34 & 0 & 0 & 50 & 19 & 0 & 0 & 70 & 160 & 0 & 0 & 160 \\
\hline $41-1$ & 378.5 & 3 & 1,4 & 1 & 4 & 3 & 3 & 4 & 5 & 420 & 370 & 79 & 660 & 280 & 100 & 68 & 210 \\
\hline
\end{tabular}

tively high values $(92 \mathrm{ppm})$ were detected only in two glauconitic, clayey siltstone samples. In the same two samples, Ni content is also increased (up to $56 \mathrm{ppm}$ ), together with $\mathrm{Fe}$ (up to $5.1 \%$ ).

The Cretaceous shales at Site 439 are low in copper, but other trace elements show concentrations quite similar to the aforementioned average values for hemipelagic sediments (Table 6).

The transition from hemipelagic sediments to pelagic clay through middle-Miocene radiolarian claystone of unit II at Site 436 is marked by prominent changes in trace-element concentrations (Figure 6). An apparent downhole increase in $\mathrm{Cu}, \mathrm{Zn}, \mathrm{Ni}, \mathrm{B}$, and to a lesser extent, Co roughly corresponds with increasing manganese content. The highest concentrations of $\mathrm{Cu}$ in
Core 436-38 (200 ppm in a sample, analyzed by atomic absorption, $330 \mathrm{ppm}$ in another sample according to spectral analysis) correspond to increased values of $\mathrm{Zn}$ (130 and $100 \mathrm{ppm}$, respectively), $\mathrm{Ni}$ ( 80 and $61 \mathrm{ppm}$ ), Co (35 and $36 \mathrm{ppm})$, and B (120 ppm). Distribution of vanadium is rather peculiar. It is most abundant (240 $\mathrm{ppm}$ ) in a sample from Core 436-35 (326 m sub-bottom) and decreases gradually downhole to $95 \mathrm{ppm}$ at the boundary with underlying pelagic clay. Chromium content is monotonous, and similar to that in common hemipelagic sediments. Silver content decreases sharply at the boundary of units I and II, being evenly low (0.04-0.07 ppm) throughout the latter.

The pelagic clay (unit IIIa at Site 436) contains the most abundant copper (160-308 ppm; average of seven 
TABLE 7 - Continued

\begin{tabular}{|c|c|c|c|c|c|c|c|c|c|c|c|c|c|c|c|c|c|c|c|c|c|c|c|}
\hline \multicolumn{4}{|c|}{$\mathrm{Ni}$} & \multicolumn{4}{|c|}{ Co } & \multicolumn{4}{|c|}{$\mathrm{Cr}$} & \multicolumn{4}{|c|}{ V } & \multicolumn{4}{|c|}{ B } & \multicolumn{4}{|c|}{$\mathrm{Ag}$} \\
\hline$<1$ & $1-10$ & $>10$ & Bulk & $<1$ & $1-10$ & $>10$ & Bulk & $<1$ & $1-10$ & $>10$ & Bulk & $<1$ & $1-10$ & $>10$ & Bulk & $<1$ & $1-10$ & $>10$ & Bulk & $<1$ & $1-10$ & $>10$ & Bulk \\
\hline 38 & 13 & 20 & 30 & 14 & 3 & 6 & 12 & 35 & 10 & 36 & 25 & 210 & 34 & 91 & 112 & 100 & 22 & 63 & 72 & 0.19 & 0.13 & 0.43 & 0.06 \\
\hline 43 & 28 & 20 & 34 & 12 & 9 & 10 & 10 & 30 & 20 & 30 & 26 & 240 & 100 & 115 & 128 & 140 & 58 & 55 & 79 & 0.29 & 0.16 & 0.17 & 0.07 \\
\hline 33 & 15 & 23 & 40 & 7 & 4 & 5 & 12 & 25 & 20 & 31 & 26 & 158 & 63 & 98 & 99 & 140 & 58 & 76 & 98 & 0.17 & 0.19 & 0.17 & 0.05 \\
\hline 29 & 28 & 18 & 28 & 5 & 6 & 4 & 6 & 19 & 26 & 23 & 18 & 120 & 115 & 76 & 83 & 81 & 76 & 49 & 76 & 0.20 & 0.35 & 0.11 & 0.11 \\
\hline 27 & 17 & 36 & 32 & 4 & 4 & 6 & 6 & 14 & 13 & 32 & 32 & 85 & 50 & 118 & 83 & 89 & 55 & 98 & 98 & 0.06 & 0.14 & 0.21 & 0.08 \\
\hline 21 & 14 & 10 & 29 & 3 & 3 & 3 & 5 & 20 & 15 & 18 & 21 & 170 & 50 & 69 & 112 & 87 & 36 & 33 & 79 & 0.17 & 0.14 & 0.07 & 0.10 \\
\hline 32 & 13 & 24 & 35 & 5 & 3 & 5 & 7 & 22 & 16 & 29 & 24 & 158 & 63 & 115 & 96 & 120 & 48 & 78 & 110 & 0.16 & 0.07 & 0.22 & 0.05 \\
\hline 41 & 18 & 20 & 29 & 10 & 5 & 6 & 8 & 38 & 25 & 29 & 25 & 210 & 85 & 93 & 120 & 135 & 58 & 52 & 87 & 0.27 & 0.19 & 0.10 & 0.17 \\
\hline 25 & 27 & 36 & 29 & 6 & 8 & 10 & 10 & 21 & 26 & 30 & 21 & 135 & 61 & 115 & 87 & 56 & 32 & 69 & 72 & 0.04 & 0.17 & 0.19 & 0.11 \\
\hline 32 & 15 & 46 & 42 & 13 & 6 & 20 & 23 & 30 & 10 & 28 & 27 & 160 & 72 & 120 & 105 & 105 & 64 & 83 & 83 & 0.17 & 0.11 & 0.39 & 0.10 \\
\hline 55 & 26 & 42 & 50 & 14 & 8 & 17 & 16 & 26 & 23 & 29 & 20 & 170 & 69 & 105 & 98 & 130 & 48 & 62 & 87 & 2.8 & 0.25 & 0.46 & 1.1 \\
\hline 22 & 20 & 23 & 32 & 3 & 4 & 5 & 7 & 11 & 16 & 18 & 20 & 73 & 54 & 93 & 83 & 87 & 56 & 95 & 110 & 0.38 & 0.30 & 0.44 & 0.91 \\
\hline 41 & 23 & 35 & 39 & 12 & 7 & 13 & 12 & 42 & 25 & 36 & 38 & 220 & 110 & 145 & 155 & 140 & 83 & 110 & 110 & 2.1 & 0.27 & 0.32 & 0.63 \\
\hline 48 & 30 & 44 & 36 & 10 & 8 & 10 & 10 & 42 & 25 & 34 & 29 & 230 & 100 & 112 & 100 & 150 & 79 & 91 & 91 & 2 & 0.49 & 0.81 & 1.9 \\
\hline 26 & 10 & 15 & 10 & 3 & 3 & 3 & 3 & 26 & 30 & 20 & 13 & 80 & 46 & 50 & 46 & 69 & 38 & 42 & 40 & 4.3 & 0.28 & 0.39 & 1.2 \\
\hline 43 & 17 & 30 & 32 & 13 & 4 & 8 & 18 & 26 & 15 & 25 & 26 & 135 & 60 & 80 & 93 & 85 & 50 & 72 & 76 & 0.52 & 0.32 & 0.82 & 0.66 \\
\hline 33 & 17 & 32 & 35 & 6 & 5 & 9 & 10 & 27 & 19 & 27 & 25 & 160 & 74 & 120 & 100 & 120 & 63 & 89 & 78 & 3.6 & 0.24 & 0.56 & 1.1 \\
\hline 38 & 19 & 35 & 33 & 6 & 4 & 9 & 8 & 27 & 17 & 32 & 26 & 140 & 68 & 110 & 91 & 100 & 50 & 91 & 78 & 0.22 & 0.10 & 0.14 & 0.02 \\
\hline 26 & 13 & 21 & 30 & 6 & 4 & 8 & 8 & 27 & 21 & 43 & 35 & 81 & 59 & 125 & 87 & 60 & 21 & 43 & 54 & 0.42 & 0.14 & 0.14 & 0.24 \\
\hline 35 & 50 & 44 & 24 & 6 & 6 & 12 & 9 & 28 & 34 & 88 & 39 & 100 & 71 & 180 & 110 & 66 & 25 & 51 & 60 & 0.43 & 0.19 & 0.44 & 0.18 \\
\hline 41 & 23 & 28 & 35 & 10 & 7 & 10 & 10 & 46 & 37 & 59 & 41 & 200 & 110 & 150 & 140 & 120 & 50 & 63 & 100 & 0.48 & 0.27 & 0.15 & 0.30 \\
\hline 30 & 24 & 22 & 33 & 7 & 6 & 11 & 12 & 23 & 24 & 32 & 33 & 130 & 76 & 79 & 110 & 100 & 44 & 40 & 68 & 0.87 & 0.34 & 0.27 & 0.26 \\
\hline 20 & 7 & 17 & 20 & 5 & 2 & 5 & 6 & 19 & 12 & 20 & 16 & 120 & 43 & 69 & 79 & 91 & 30 & 49 & 63 & 0.24 & 0.11 & 0.14 & 0.11 \\
\hline 21 & 10 & 28 & 19 & 3 & 3 & 8 & 4 & 19 & 15 & 31 & 18 & 110 & 42 & 57 & 45 & 91 & 50 & 37 & 72 & 0.11 & 0.25 & 0.74 & 0.22 \\
\hline 22 & 17 & 20 & 32 & 4 & 4 & 4 & 5 & 17 & 23 & 26 & 30 & 91 & 79 & 56 & 63 & 91 & 50 & 40 & 71 & 0.22 & 0.32 & 0.40 & 0.19 \\
\hline 17 & 12 & 20 & 20 & 3 & 2 & 5 & 5 & 14 & 14 & 23 & 15 & 95 & 43 & 43 & 47 & 76 & 46 & 33 & 72 & 0.18 & 0.16 & 0.45 & 0.19 \\
\hline 25 & 18 & 38 & 43 & 7 & 3 & 11 & 9 & 18 & 11 & 29 & 13 & 100 & 35 & 79 & 54 & 95 & 35 & 40 & 91 & 0.15 & 0.14 & 0.54 & 0.33 \\
\hline 22 & 9 & 22 & 25 & 4 & 1 & 4 & 5 & 17 & 7 & 27 & 19 & 85 & 20 & 68 & 57 & 93 & 28 & 44 & 72 & 0.98 & 0.24 & 0.26 & 0.48 \\
\hline 33 & 24 & 22 & 34 & 8 & 6 & 7 & 11 & 25 & 25 & 34 & 30 & 170 & 72 & 130 & 130 & 120 & 42 & 42 & 85 & 0.13 & 0.13 & 0.05 & 0.06 \\
\hline 28 & 13 & 8 & 21 & 5 & 4 & 3 & 6 & 24 & 17 & 14 & 17 & 170 & 60 & 46 & 91 & 60 & 30 & 18 & 50 & 0.11 & 0.36 & 0.15 & 0.06 \\
\hline 41 & 18 & 15 & 36 & 13 & 5 & 3 & 13 & 25 & 16 & 25 & 25 & 180 & 55 & 40 & 100 & 83 & 29 & 25 & 54 & 0.06 & 0.14 & 0.18 & 0.04 \\
\hline 44 & 30 & 24 & 36 & 10 & 9 & 11 & 9 & 23 & 26 & 28 & 38 & 260 & 110 & 130 & 160 & 140 & 66 & 60 & 100 & 0.23 & 0.17 & 0.17 & 0.10 \\
\hline 17 & 18 & 19 & 20 & 5 & 5 & 5 & 7 & 20 & 22 & 28 & 28 & 95 & 72 & 79 & 95 & 72 & 55 & 72 & 79 & 0.14 & 0.23 & 0.25 & 0.08 \\
\hline 44 & 28 & 18 & 24 & 14 & 9 & 4 & 9 & 34 & 23 & 25 & 29 & 140 & 69 & 46 & 81 & 100 & 53 & 48 & 79 & 1.8 & 0.87 & 0.85 & 0.19 \\
\hline 40 & 34 & 17 & 20 & 22 & 18 & 7 & 14 & 40 & 34 & 22 & 33 & 100 & 69 & 37 & 68 & 100 & 79 & 38 & 72 & 1.5 & 0.52 & 100 & 0.55 \\
\hline 29 & 24 & 7 & 20 & 20 & 12 & 2 & 12 & 52 & 25 & 7 & 23 & 130 & 57 & 13 & 93 & 72 & 40 & 14 & 60 & 6.3 & 0.46 & 0.22 & 0.41 \\
\hline 39 & 30 & 38 & 24 & 26 & 21 & 20 & 14 & 5 & 30 & 39 & 25 & 130 & 70 & 110 & 91 & 60 & 46 & 60 & 60 & 0.34 & 0.09 & 0.60 & 0.21 \\
\hline 29 & 29 & 29 & 25 & 18 & 22 & 15 & 20 & 20 & 23 & 30 & 28 & 130 & 63 & 95 & 100 & 72 & 66 & 63 & 72 & 0.34 & 0.69 & 1.2 & 0.40 \\
\hline 20 & 31 & 11 & 23 & 16 & 18 & 5 & 13 & 14 & 22 & 15 & 20 & 80 & 87 & 38 & 68 & 52 & 72 & 30 & 55 & 0.52 & 0.27 & 0.58 & 0.40 \\
\hline 43 & 38 & 23 & 36 & 25 & 24 & 15 & 22 & 22 & 23 & 21 & 29 & 95 & 76 & 76 & 83 & 91 & 72 & 66 & 76 & 0.25 & 0.07 & 0.06 & 0.07 \\
\hline 49 & 44 & 44 & 44 & 40 & 31 & 21 & 23 & 25 & 26 & 33 & 33 & 330 & 200 & 160 & 240 & 91 & 63 & 46 & 83 & 0.57 & 0.30 & 2.1 & 0.05 \\
\hline 83 & 50 & 60 & 34 & 44 & 31 & 38 & 24 & 36 & 26 & 32 & 26 & 170 & 100 & 130 & 170 & 160 & 91 & 110 & 95 & 0.22 & 0.13 & 0.06 & 0.04 \\
\hline 53 & 49 & 30 & 64 & 32 & 25 & 15 & 36 & 27 & 22 & 20 & 40 & 120 & 76 & 60 & 110 & 140 & 79 & 27 & 140 & 0.10 & 0.03 & 0.07 & 0.04 \\
\hline 110 & 59 & 26 & 61 & 66 & 34 & 12 & 36 & 48 & 27 & 15 & 38 & 150 & 91 & 48 & 95 & 150 & 91 & 69 & 120 & 0.27 & 0.11 & 0.05 & 0.07 \\
\hline 91 & 46 & 17 & 43 & 48 & 21 & 18 & 19 & 38 & 22 & 12 & 24 & 230 & 76 & 63 & 95 & 170 & 66 & 43 & 110 & 0.09 & 0.06 & 0.09 & 0.05 \\
\hline 110 & 94 & 63 & 105 & 32 & 36 & 23 & 35 & 15 & 28 & 25 & 29 & 68 & 89 & 87 & 95 & 87 & 72 & 52 & 130 & 0.07 & 0.36 & 0.4 & 0.05 \\
\hline 115 & 70 & 230 & 190 & 110 & 87 & 54 & 100 & 22 & 30 & 46 & 33 & 180 & 100 & 140 & 140 & 140 & 79 & 79 & 160 & 0.17 & 0.06 & 0.14 & 0 \\
\hline 200 & 270 & 230 & 240 & 97 & 79 & 115 & 75 & 42 & 30 & 42 & 46 & 200 & 93 & 65 & 180 & 150 & 74 & 48 & 190 & 0 & 0 & 0 & 0 \\
\hline 200 & 0 & 0 & 260 & 54 & 0 & 0 & 85 & 21 & 0 & 0 & 40 & 140 & 0 & 0 & 120 & 140 & 0 & 0 & 100 & 0 & 0 & 0 & 0 \\
\hline 110 & 42 & 32 & 76 & 12 & 12 & 7 & 17 & 57 & 38 & 40 & 57 & 430 & 240 & 100 & 340 & 190 & 35 & 33 & 91 & 0.03 & 0.3 & 0.06 & 0 \\
\hline
\end{tabular}

analyses by both methods $228 \mathrm{ppm}$ ), nickel (76-430 ppm; average of the same samples $223.7 \mathrm{ppm})$, Co (17-170 ppm; average $86 \mathrm{ppm})$, and zinc (70-310 ppm; average $129 \mathrm{ppm}$, if an extreme value of $660 \mathrm{ppm}$ is excluded). Lead and boron concentrations are also higher than in other types of sediments. The pelagic clay is enriched in vanadium (up to $340 \mathrm{ppm}$ ) as well, whereas chromium content is approximately equal to that in hemipelagic sediments. Silver was not found at all (Table 7).

Thus, the pelagic clay at Site 436 is characterized by the same geochemical features as the Holocene pelagic clay of the Pacific (Skornyakova, 1976; Boström, 1976; and others). By its average copper, cobalt, lead, and zinc contents, the pelagic clay at Site 436 resembles North Pacific eupelagic clay, but average nickel content from our analyses is considerably greater, more like that for equatorial-belt radiolarian clay, which averages 211 ppm (Skornyakova, 1976).

The trace elements in which the pelagic clay is enriched $(\mathrm{Cu}, \mathrm{Zn}, \mathrm{Pb}, \mathrm{Ni}, \mathrm{Co}, \mathrm{V}, \mathrm{B})$ all tend to concentrate in the finest size fraction. However, high concentrations of $\mathrm{Ni}, \mathrm{Co}$, and $\mathrm{V}$ occur in some coarse fractions as well, likely being associated with manganese micronodules.

A brown chert sample from Core 436-42 shows rather low concentrations of $\mathrm{Cu}, \mathrm{Zn}, \mathrm{Ni}, \mathrm{Co}$, and $\mathrm{Cr}$ (Table 6), apparently because of "dilution" by "excess" authigenic silica. If calculated on an "excess"'-SiO ${ }_{2}$-free basis, the concentrations appear to be comparable with those for pelagic clay, or even greater $(\mathrm{Cu}, 358 \mathrm{ppm} ; \mathrm{Zn}, 205$ ppm; Ni, 157 ppm; Co, 319 ppm; Cr, 24 ppm). The rela- 
TABLE 8

Average Concentrations of Elements in the Japan Trench Sediments

\begin{tabular}{|c|c|c|c|c|}
\hline \multirow[b]{2}{*}{ Component } & \multicolumn{2}{|c|}{$\begin{array}{l}48 \text { Samples Analyzed } \\
\text { for Minor Elements }\end{array}$} & \multicolumn{2}{|c|}{$\begin{array}{l}40 \text { Samples of Hemipelagic } \\
\text { Sediments (middle } \\
\text { Miocene to Quaternary) }\end{array}$} \\
\hline & Average & $\pm \delta$ & Average & $\pm \delta$ \\
\hline "excess" $\mathrm{SiO}_{2}(\%)$ & 28.4 & 15.5 & 32.1 & 14.2 \\
\hline $\mathrm{Al}(\%)$ & 5.7 & 1.7 & 5.2 & 1.4 \\
\hline $\mathrm{Fe}(\%)$ & 3.2 & 0.9 & 3.1 & 0.8 \\
\hline $\mathrm{Ti}(\%)$ & 0.3 & 0.1 & 0.3 & 0.1 \\
\hline $\mathrm{Cu}$ (ppm) & 64.6 & 58.1 & 62.1 & 38.1 \\
\hline $\mathrm{Zn}(\mathrm{ppm})$ & 92.8 & 22.4 & 92.3 & 16.9 \\
\hline $\mathrm{Ni}(\mathrm{ppm})$ & 51.0 & 65.4 & 39.7 & 12.4 \\
\hline Co (ppm) & 25.0 & 27.4 & 20.2 & 9.8 \\
\hline $\mathrm{Cr}(\mathrm{ppm})$ & 34.6 & 11.1 & 34.7 & 11.6 \\
\hline
\end{tabular}

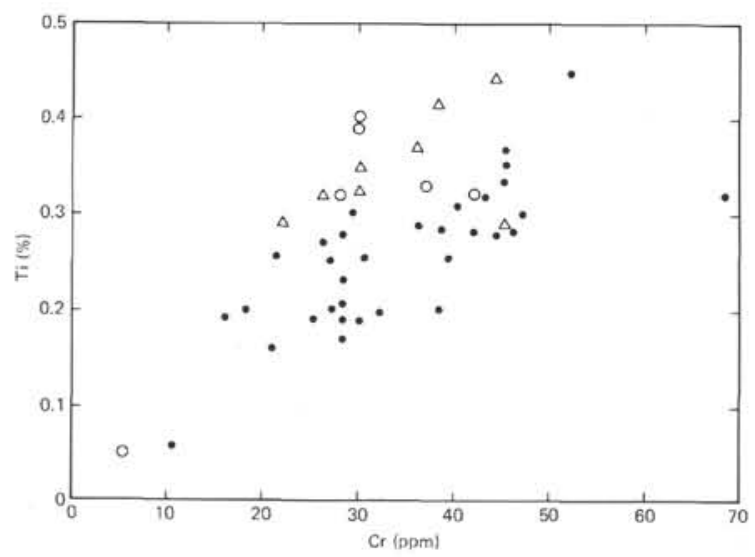

Figure 8. Relation between $\mathrm{Cr}$ and Ti in the Japan Trench sediments. Symbols as in Figure 7.

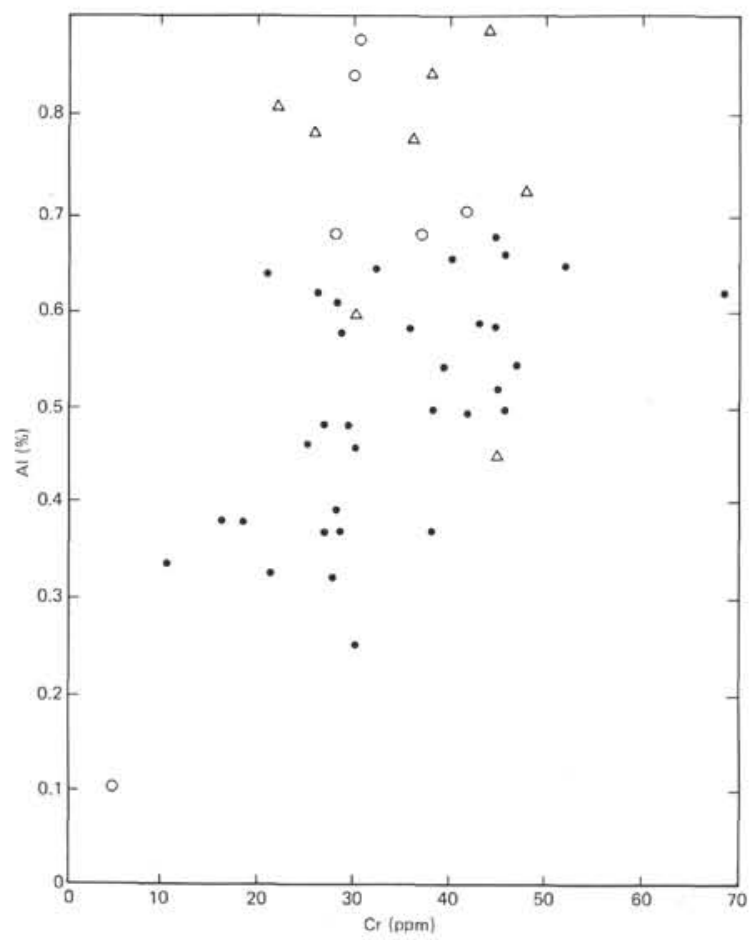

Figure 9. Relation between $\mathrm{Cr}$ and $\mathrm{Al}$ in the Japan Trench sediments. Symbols as in Figure 7.

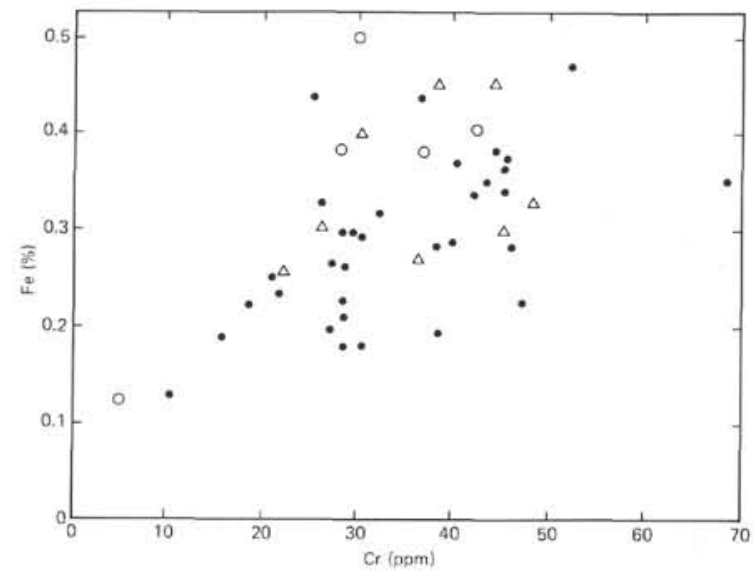

Figure 10. Relation between $\mathrm{Cr}$ and $\mathrm{Fe}$ in the Japan

Trench sediments. Symbols as in Figure 7.

tive abundances of the elements differ from those in pelagic clay. Most significant are an increase in cobalt and a decrease in nickel with respect to the others.

\section{SUMMARY AND INTERPRETATIONS}

The Japan Trench sedimentary section drilled during DSDP Legs 56 and 57 is composed mainly of Neogene (middle to upper Miocene through Pliocene) andQuaternary (including Holocene) hemipelagic diatomaceous mud, with variable amounts of vitric ash, which occurs both as thin silt- and sand-size tephra interbeds and as an admixture to the diatomaceous and terrigenous material (see site reports, this volume). The hemipelagic sediments were the major objective of our geochemical study. In addition we studied the lower- to middle-Miocene turbidites, upper-Oligocene sandstones and siltstones, and Cretaceous shale from the upper trench slope terrace edge (Site 438, 439), as well as the pre-Neogene pelagic clay and chert from the oceanic slope (Site 436), which differ considerably from the hemipelagic sediments in their chemical composition.

Chemical composition of the hemipelagic sediments on the whole is rather monotonous and resembles that of the Holocene hemipelagic mud, particularly that of diatomaceous mud widespread in the western North Pacific and in the Aleutian, Kurile-Kamchatka, and Japan Trenches. The characteristic features are increased total silica and biogenic silica content as compared with common terrigenous mud or hemipelagic clay, along with correspondingly decreased concentrations of most other chemical constituents, such as $\mathrm{Ti}$, $\mathrm{Al}, \mathrm{Fe}, \mathrm{Cr}, \mathrm{Sn}$, and $\mathrm{V}$. Like all known hemipelagic sediments, the Japan Trench sediments are low in manganese, which was leached during early diagenesis under reducing conditions caused by bacterial decomposition of organic matter and sulfate-reduction processes. Such trace elements as $\mathrm{Cu}, \mathrm{Ni}, \mathrm{Co}$, and $\mathrm{Pb}$, which tend to increase their concentration in pelagic sediments, are relatively low in the studied hemipelagic sediments.

Variations in bulk chemical composition of the hemipelagic sediments are related mainly to the variable 
biogenic-silica content, indicated both by direct chemical determination of "amorphous" silica and by calculated "excess" silica. The biogenic silica apparently serves as a "dilutant". Such interrelations are expressed by the inverse relations of the elements with silica on geochemical graphs for different sites (Figures 2-6), and by a negative correlation of "excess" silica with $\mathrm{Al}, \mathrm{Fe}$, and Ti. (Table 9). A rather weak, but important negative correlation of "excess" $\mathrm{SiO}_{2}$ with $\mathrm{Zn}$, and $\mathrm{Cr}$, and an insignificant negative correlation with $\mathrm{Cu}$ and $\mathrm{Ni}$, indicates that these elements are "diluted" to a certain extent by biogenic silica as well.

The biogenic silica distribution patterns and corresponding changes in other chemical constituents may be explained best by biological productivity.The highproductivity zone in the western North Pacific, which results in the accumulation of hemipelagic biogenic silica first appeared during the Miocene (probably the middle Miocene). The productivity was highest during the early Pliocene, as indicated by the greatest biogenic silica content in the hemipelagic sediments, which decreases then in the Pleistocene.

However, the percentages of "excess" $\mathrm{SiO}_{2}$ and "amorphous" $\mathrm{SiO}_{2}$ are valid criteria of biological productivity only if the accumulation rate of non-biogenic matter is assumed to be about constant. Because the assumption is rather inconceivable, we calculated the accumulation rates of both "excess" $\mathrm{SiO}_{2}$ and "amorphous" $\mathrm{SiO}_{2}$ for dated stratigraphic intervals at each site, except for the scarcely studied Site 441 (Table 10). The results basically are in agreement with the general evolution trends inferred from the percentages, but they reveal some new details.

At all sites, the most extensive biogenic-silica accumulation occurred during the Pliocene, but the maximum values fall in the early Pliocene at Sites 435 and 434, whereas at Sites 440 and 436 accumulation was faster during the late Pliocene, and it was almost constant during the Pliocene at Site 438.

The absolute maximum of biogenic silica accumulation was detected in the late Pliocene at Site 440 (Table 10). The early-Pliocene and Pleistocene intervals at this site show extreme accumulation rates of both "amorphous" $\mathrm{SiO}_{2}$ and "excess" $\mathrm{SiO}_{2}$ as well. The extensive silica accumulation during the last $5 \mathrm{~m}$.y. hardly can be interpreted to mean local high productivity. More likely, hemipelagic sedimentation was accelerated by down-

TABLE 9

Correlation Coefficients Between Several Major and Trace Elements in the Japan Trench Sediments ${ }^{a}$

\begin{tabular}{lcccccccc}
\hline & $\mathrm{Al}$ & $\mathrm{Fe}$ & $\mathrm{Ti}$ & $\mathrm{Cu}$ & $\mathrm{Zn}$ & $\mathrm{Ni}$ & $\mathrm{Co}$ & $\mathrm{Cr}$ \\
\hline "excess" SiO 2 & -0.96 & -0.81 & -0.83 & $(-0.3)$ & $-0.45 \mathrm{~b}$ & $(-0.31)$ & - & $-0.53^{\mathrm{b}}$ \\
$\mathrm{Al}$ & & 0.76 & 0.86 & - & $0.46^{\mathrm{b}}$ & $(0.36)$ & $(0.39)$ & $0.55^{\mathrm{b}}$ \\
$\mathrm{Fe}$ & & & 0.81 & $(0.39)$ & 0.54 & 0.45 & 0.46 & $0.52^{\mathrm{b}}$ \\
$\mathrm{Ti}$ & & & & - & 0.40 & $(0.35)$ & - & 0.72 \\
$\mathrm{Cu}$ & & & & & 0.60 & 0.72 & 0.71 & - \\
$\mathrm{Zn}$ & & & & & 0.68 & 0.67 & - \\
$\mathrm{Ni}$ & & & & & & 0.95 & - \\
$\mathrm{Co}$ & & & & & & & & - \\
\hline
\end{tabular}

a The correlations are calculated for samples analyzed by atomic absorption. Numbers in barentheses indicate insignificant correlations.

${ }^{b}$ Calculated for hemipelagic sediments only. slope transportation of both terrigenous and biogenic material.

The next zone of accumulation of abundant biogenic silica in the Pliocene is on the upper trench slope (Site 438). Here, the highest accumulation rates of "excess" $\mathrm{SiO}_{2}$ were recorded in both the early and late Pliocene, but "amorphous" $\mathrm{SiO}_{2}$ shows a greater value for the late Pliocene. The accumulation was less extensive during the late Miocene, and it decreases sharply in the Pleistocene, corresponding to the silica percentages in these intervals and hence confirming the biological productivity evolution patterns mentioned before.

The silica-accumulation rates appeared to be much lower at Site 435 , instead of high percentages of both "excess" $\mathrm{SiO}_{2}$ and "amorphous" $\mathrm{SiO}_{2}$ in the Pliocene section. Hemipelagic sedimentation at this site likely has been restricted somewhat by currents and lesser amounts of biogenic silica were accumulated, as compared with other sites of the inner trench slope.

Biogenic-silica-accumulation rates on the oceanic trench slope have been slowest for each correlated stratigraphic interval, thus pointing to a regular oceanward decrease in biological productivity. Nevertheless, there was a regular increase in silica accumulation from the late Miocene through the early Pliocene to the late Pliocene, whereas in the Pleistocene the accumulation rate of "excess" silica decreased, but that of "amorphous" silica even increased slightly (Table 10).

Besides biogenic silica, vitric ash also should diminish somewhat concentrations of $\mathrm{Fe}, \mathrm{Ti}, \mathrm{Mg}$, and those trace elements which are low in acidic (rhyolitic-dacitic) volcanic products $(\mathrm{Cr}, \mathrm{Ni}, \mathrm{Co})$, but we have no quantitative methods to evaluate this influence.

The ratios of some major elements $(\mathrm{Al} / \mathrm{Ti}, \mathrm{Fe} / \mathrm{Al}$, $\mathrm{Fe} / \mathrm{Ti}, \mathrm{Mn} / \mathrm{Al}, \mathrm{Ti} / \mathrm{Fe}$ ) allow the exclusion of the "dilution" effect of biogenic silica, and they are expected to indicate the composition of non-biogenic matter. This comprises terrigenous and volcanogenic particulate matter (clay and clastics) and authigenic constituents. Aluminum and titanium are hypothetically associated almost entirely with the particulate matter, whereas iron and manganese are partially incorporated in authigenic minerals such as pyrite, siderite, rhodochrosite, and glauconite. Therefore, the $\mathrm{Al} / \mathrm{Ti}$ ratio is indicative of the particulate matter, whereas ratios of $\mathrm{Fe}$ and $\mathrm{Mn}$ to $\mathrm{Al}$ and Ti may be used to indicate the "excess" (authigenic) $\mathrm{Fe}$ and $\mathrm{Mn}$ proportions (Boström, 1976; Strakhov, 1976).

All ratios demonstrate a close resemblance between the non-biogenic matter of the Japan Trench sediments and common terrigenous material derived from continents. There is a strong positive correlation between $\mathrm{Ti}, \mathrm{Fe}$, and $\mathrm{Al}$ (Table 9), which should be even stronger if calculated for hemipelagic sediments only. Therefore, all three elements are likely of similar origin, being associated mainly wtih particulate matter.

Some variations in the $\mathrm{Al} / \mathrm{Ti}$ ratio correspond to a more or less abundant vitric-ash admixture, which tends to increase the ratio because of the extremely low titanium content in the acidic glass. An almost constant $\mathrm{Fe} / \mathrm{Ti}$ ratio, as compared with a more variable $\mathrm{Fe} / \mathrm{Al}$ 
TABLE 10

Accumulation Rates of "Amorphous" $\mathrm{SiO}_{2}$ and "Excess" $\mathrm{SiO}_{2}$ in the Japan Trench during the Late Neogene and Pleistocene (g per $\mathrm{cm}^{2}$ per $1000 \mathrm{yr}$ )

\begin{tabular}{|c|c|c|c|c|c|c|c|c|c|c|c|}
\hline Late Pliocene & $1.6-2.8$ & 0.89 & 3.08 & 0.40 & 0.79 & 1.98 & 6.09 & 0.17 & 0.35 & 0.25 & 0.17 \\
\hline Early Pliocene & $2.8-5.1$ & 0.87 & 3.05 & $0.41^{\mathrm{a}}$ & $1.12^{\mathrm{a}}$ & 0.99 & 3.60 & 0.98 & 2.62 & 0.12 & 0.34 \\
\hline Late Miocene & $5.1-11.3$ & 0.29 & 1.24 & - & - & - & - & 0.57 & 1.76 & 0.11 & 0.24 \\
\hline
\end{tabular}

${ }^{\mathrm{a}}$ Sedimentation rate extrapolated from the late Pliocene.

ratio, indicates that the greater portions of iron and titanium are bound up in the same clastic minerals, above all titanomagnetite. Therefore, an increase in the $\mathrm{Fe} / \mathrm{Al}$ ratio without any increase in the $\mathrm{Fe} / \mathrm{Ti}$ ratio points rather to clastic titanomagnetite than to authigenic $\mathrm{Fe}$ minerals, although the latter may be responsible for a minor portion of the "excess" iron as well. Pyrite is particularly common at the lower landward slope of the Japan Trench, as indicated by mineralogical study and smear-slide descriptions. Here, under strongly reducing conditions (free $\mathrm{H}_{2} \mathrm{~S}$ in sediments), the mobile "hydrogenous" forms of iron should have been completely reduced to $\mathrm{Fe}^{2+}$ and precipitated as sulfides. In these pyrite-rich sediments, both the $\mathrm{Fe} / \mathrm{Al}$ and $\mathrm{Fe} / \mathrm{Ti}$ ratios tend to increase.

We investigated correlations between trace elements determined by atomic absorption (Table 9) and, separately, those determined by spectral analysis (Figure 11). Although the Table 8 figures were obtained partially using data from all lithologic groups, the number of hemipelagic sediment samples is much greater than the others taken together, so the results should be representative for hemipelagic sediments as well.

The positive correlations of various trace elements with $\mathrm{Al}, \mathrm{Ti}$, and $\mathrm{Fe}$ (Table 9) become weaker in the succession $\mathrm{Cr}-\mathrm{Zn}-\mathrm{Ni}-\mathrm{Co}-\mathrm{Cu}$, which probably reflects the strength of the relationship of the elements with particulate matter, versus their "hydrogenous" (adsorbed or authigenic) forms. Therefore, $\mathrm{Cr}$ and $\mathrm{Zn}$ are assumed to associate mainly with particulate matter; $\mathrm{Ni}$ and $\mathrm{Co}$ correlated positively only with $\mathrm{Fe}$, whereas correlations with $\mathrm{Al}$ and $\mathrm{Ti}$ are unimportant; and $\mathrm{Cu}$ does not correlate with particulate-matter indicators at all. The absence of correlation is likely indicative of the diverse behavior of $\mathrm{Cu}$, which is both "particulate" and "hydrogenous."

Rather strong positive correlations of $\mathrm{Ni}$, Co (Figure 12) and $\mathrm{Cu}$ with each other (Table 9) is confirmed in several cases by correlation diagrams for separate sites and size fractions (Figure 11). The correlations were found mainly in the clay fraction of the hemipelagic sediments, but in some cases appear also in coarser fractions and bulk samples. Other correlations on the diagrams show very complicated and rather irregular patterns. We failed to infer any certain genetic interpretation from the data.

As shown by lithologic description, the Miocene turbidites and upper-Oligocene sandstones and siltstones of the inner slope terrace edge differ from the hemipelagic sediments by abundant sand- and silt-size terrigenous material and by lower content of clay and biogenic opal. These differences are reflected in their geochemistry as decrease in the total silica and particularly in biogenic-silica content; increase in aluminum and the $\mathrm{Al} / \mathrm{Ti}$ ratio; and decrease in the $\mathrm{Fe} / \mathrm{Al}$ ratio. Such trace elements as $\mathrm{Cu}$ and $\mathrm{Zn}$, which are associated with clay, tend to decrease as well, whereas others do not change their abundances, or even increase $(\mathrm{Cr})$.

The transition from hemipelagic sediments to pelagic at Site 436, through intermediate unit II, is marked by changes in both major and trace elements: biogenic silica decreases to zero in the pelagic clay, and total silica also decreases to values close to those for Holocene eupelagic clay of the Pacific. Aluminum content increases because of disappearance of biogenic silica, and the $\mathrm{Al} / \mathrm{Ti}$ ratio decreases, likely reflecting disappearance of acidic vitric ash. However, most significant is the sharp increase in Fe and, especially, Mn concentrations, which are related to the transition from reducing (hemipelagic) to oxidizing conditions of early diagenesis.

However, oxidizing conditions alone are not sufficient to explain the high manganese content and corresponding increase in certain trace elements (above all, $\mathrm{Cu}$ and $\mathrm{Ni}$ ) in the pelagic clay. We have to assume a pelagic environment of extremely low sedimentation rate, similar to that in central subtropical areas of the modern Pacific, where eupelagic (partially authigenic) red clay of similar chemical appearance is accumulating (Skornyakova, 1976). An additional (exhalative?) source of Mn may have acted as well, resulting in the high $\mathrm{Mn} /$ $\mathrm{Fe}, \mathrm{Mn} / \mathrm{Al}$, and $\mathrm{Mn} / \mathrm{Ti}$ ratios.

The dark-brown chert recovered at Site 436 geochemically resembles the overlying pelagic clay, if "excess" authigenic silica is excluded from consideration. It shows increased $\mathrm{Fe} / \mathrm{Ti}$ and $\mathrm{Fe} / \mathrm{Al}$ ratios and high $\mathrm{Mn} / \mathrm{Al}$ and $\mathrm{Mn} / \mathrm{Ti}$ ratios and is relatively enriched in those trace elements which are characteristic of pelagic clay, 
Site 435
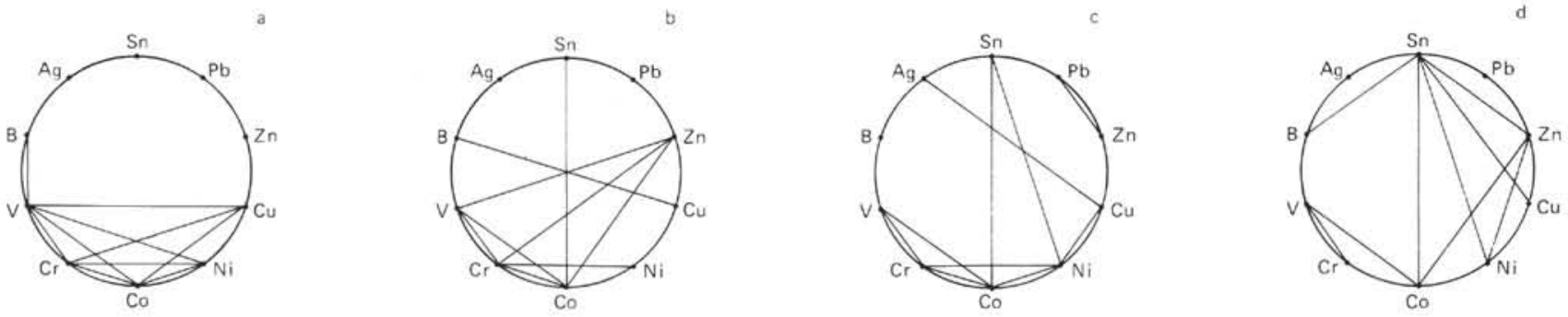

Site 434
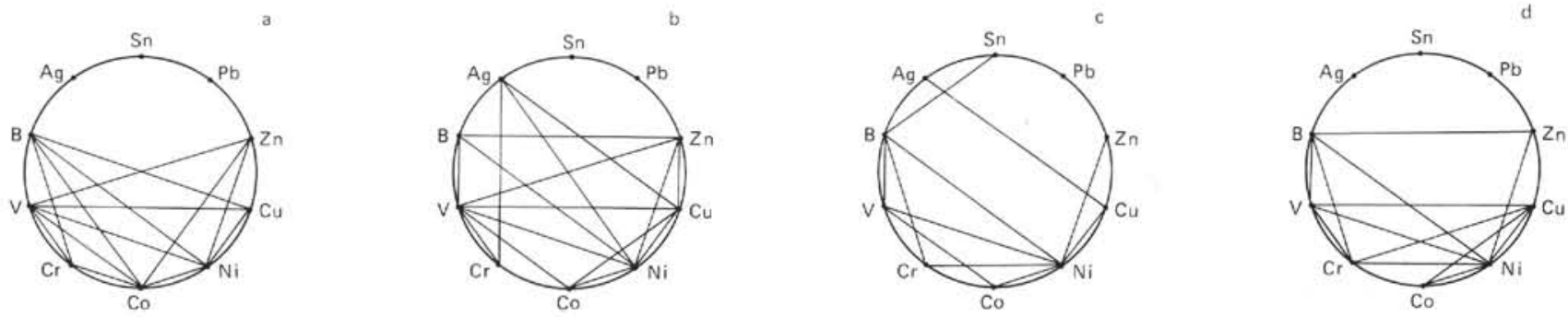

Site 436 (unit 1)


Site 436 (unit II)
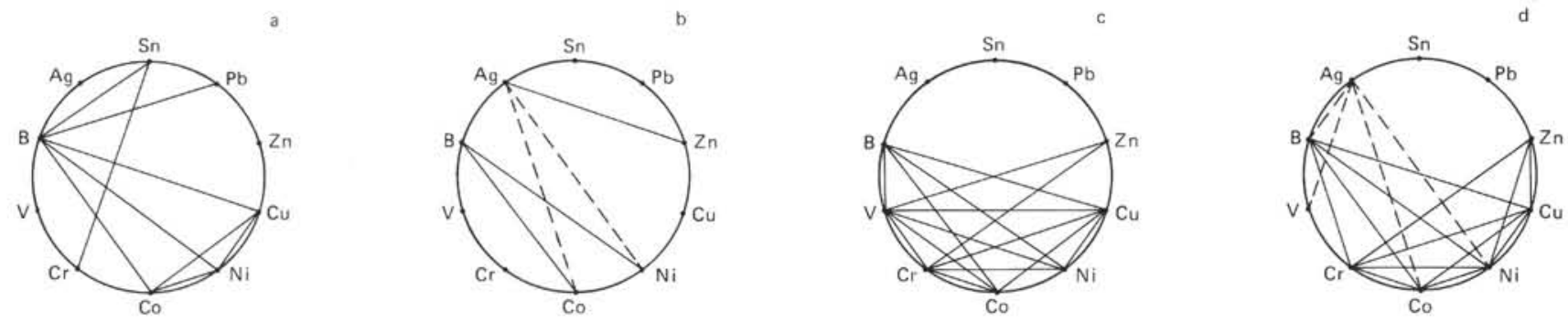

Site 436 (unit III)


Figure 11. Correlation diagrams of trace elements in the Leg 56 sediments, as determined by spectral analysis. Solid lines indicate important positive correlations; dotted lines indicate important negative correlations: a, fraction less than $1 \mu \mathrm{m}$; b, fraction $1-10 \mu \mathrm{m}$; c, fraction coarser than $10 \mu \mathrm{m} ; \mathrm{d}$, bulk samples. 


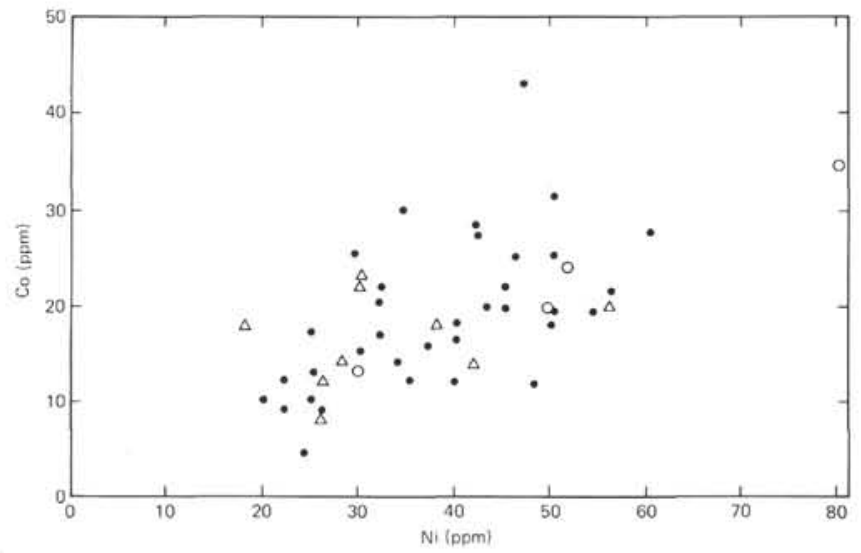

Figure 12. Relation between $\mathrm{Co}$ and $\mathrm{Ni}$ in the Japan Trench sediments. Symbols as in Figure 7.

although their interrelations are different. We assume that the cherts are formed after pelagic clay by diagenetic silicification.

\section{ACKNOWLEDGMENTS}

The authors gratefully acknowledge Dr. M. Nesterova for competent direction of the analytical procedures and Prof. P. Bezrukov for support of this work. We thank the crew and technical staff on board the Glomar Challenger for collection of core samples. We are grateful to Dr. N. Skornyakova and Dr. Y. Bogdanov (both of the Institute of Oceanology, U.S.S.R. Academy of Sciences) for critical review of the paper.

\section{REFERENCES}

Boström, K., 1976. Particulate and dissolved matter as sources for pelagic sediments. Stockholm Contr. Geol., 30(2), 18-79.

Gordeev, V. V., and Lisitzyn, A. P., 1979. Microelements. Chemistry of the Ocean: Moscow (Nauka).

Repechka, M. A., 1974. Ash layers in bottom sediments in the transitional zone between Asian continent and Pacific ocean. Problems of the Geology and Geophysics of the Marginal Seas of the Northwest Pacific: Vladivostok (U.S.S.R. Acad. Sci.), pp. 26-41.

Skornyakova, N. S., 1976. Dispersed Fe, Mn, Ti, and some minor elements in the Pacific sediments. In Bezrukov, P. L. (Ed.), Ferromanganese Nodules of the Pacific Ocean: Moscow (Nauka), pp. 168-189.

Strakhov, N. M., 1976. The geochemical problems of Recent oceanic lithogenesis. Trans. Geol. Inst. U.S.S.R. Acad. Sci., 292, 20-30.

Vinogradov, A. P., 1962. Average concentrations of elements in main magmatic rocks of the Earth's crust. Geokhimia, 7, 555 . 